\title{
Publieke Pastorale Leiers 2: Roeping, Werwing, Keuring, Opleiding, Ordening
}

\author{
Malan Nel \\ (Universiteit Pretoria)
}

\section{ABSTRACT \\ Public Pastoral Leaders 2: Calling, Recruitment, Screening, Training and Ordination}

In the first article it was attempted to provide insight into the corporate nature of being called to ministry. The article also tried to discern what the specifics of the ministry of the public pastoral leader were. Equally important what I call in this article the teleological core of theological education. I want to build upon the concepts established in the first article. I explore the contributions of a number of well-known scholars who devoted much of their research to this field: Schner, Farley, Wood, Hough and Cobb, Heitink, Van der Ven and others. The ultimate issue is that there is some consensus about the telos of theological education. It is phrased differently and the different dimensions are indeed complementary. Concepts like 'vision and discernment', 'critical reflection' 'reflective practitioner', 'hermeneutical-communicative competence' and others are being discussed as it relate to the core research problem as described in article number 1. In this article I also explore the implications of the departure points for the praxis of recruiting, screening and training of future public pastoral leaders. The article points towards necessary changes that need to take place to get the local church involved in recruitment and screening - taking it serious that 'we' are all in the ministry. It also describes how a few churches are managing the process. In doing this, the place of the denominational community of churches is also emphasized and described.

\section{INLEIDEND}

In die vorige artikel is veral aandag gegee aan wat ek sou noem ' $\mathrm{n}$ meer verantwoordelike en korporatiewe verstaan van roeping. Klem is geplaas op die verband tussen die identiteit en roeping van die gemeente. Die gemeente is per definisie ingeskakel by die werk waarmee God in hierdie wêreld besig is. Hierbinne vind die publieke pastorale leier as gawe van God aan die gemeente sy of haar 
identiteit. Die vraag wat verder beantwoord moet word is wat die aard en doel van hierdie persoon se opleiding behels.

\section{PERSPEKTIEWE OP TEOLOGIESE OPLEIDING}

Ek het reeds my voorneme verklaar om nie die noodsaak van opleiding te bespreek nie. Ook nie sake soos detail, inhoud van kurrikula of die saak van kurrikulering as sodanig nie. Uit die aard van die saak sal onderstaande daarmee verband hou en selfs na motivering klink. Die bedoeling is eerder om die 'waarvoor' van opleiding word in verband te plaas. In hierdie verband is die rol van teologiese opleiding ter tafel.

\subsection{Teleologiese kern in teologiese opleiding}

\subsubsection{G P Schner}

Schner verklaar dat die bedoeling van sy boek is 'to discover theological issues about theological education'. Hy verkies om nie die gewone kategorieë te bespreek soos die universitêre karakter van opleiding, is dit klassiek, akademies, intellektueel, kerklik en so meer nie. Hierdie kategorieë is natuurlik nie onbelangrik nie, maar hy verkies ' $\mathrm{n}$ invalshoek wat min of meer ook myne is in die volgende paragrawe: 'I have presumed that the proper understanding of how those characteristics are realized within ministry is to be found in discovering what it means for minister or priest to be professional, practical and devoted ${ }^{1}$. In hierdie verband bespreek hy dan drie werke wat vir hierdie navorsing van groot belang is: Farley, Hough en Cobb, en Wood. Al drie werke is in ' $n$ bepaalde sin 'reaksies' op die tradisionele model van teologiese opleiding. In hierdie model was die hart meer dogmaties of sistematies van aard en gerig op die 'ontwikkeling van ' $n$ persoonlike verhouding met $\mathrm{God}^{2}$ '. Die nadeel was en is die 'informatiewe' karakter van hierdie opleiding en dat studente nie genoegsaam nie (of glad nie) leer 'to think theologically in their ministry, integrating that theological knowledge with Biblical, historical, and pastoral learning, ${ }^{3}$.

Voordat voortgegaan word met die bespreking van die bydraes waarna Schner verwys en bespreek, is dit nodig om 'n oomblik stil te

1 Schner (1993:xii).

2 Schner (1933:18-19).

3 Schner (1933:19). 
staan by die derde saak waarna hy verwys naamlik 'are they devoted $?^{4}$. Dit is sy oortuiging dat die liturgiese ervaring van studente verdiep moet word. Binne die uitgangspunt van hierdie navorsing naamlik die kritiese belang van die identiteit van die gemeente beteken dit dat gemeentes met ryk en egte liturgiese ervarings ook 'toegewyde' geroepenes kan 'lewer'. Schner verwys na ' $n$ artikel van Hall waarin hy drie geestelike kwaliteite as basies tot dissipelskap beskou naamlik 'covenantal commitment, discerning discipline, and apostolic responsibility ${ }^{5}$. Al drie herinner ons aan die radikale prioriteit van God se handeling wat dissipelskap moontlik makk. Schner skryf onder andere hoe 'covenantal commitment does capture in a phrase what spiritual formation is: appropriation, assimilation, and internalization of the faith tradition which makes possible and nourishes personal commitment and the realization of particular God-given gifts and vocation', In ' $n$ hoofstuk waar hy sy 'drietal' in verband bring met identiteit in die bediening maak hy ' $n$ saak uit dat hierdie identiteit rasioneel is. Hy toon aan dat daar wel pogings is wat ' $\mathrm{n}$ soort spiritualiteit kweek wat, soos O'Meara dit stel, die bediening romantiseer. ${ }^{7}$ Hy pleit dan vir ' $n$ verstaan van identiteit wat werk daarmee dat dit iets is wat ek het voordat ek dit eintlik weet 'and yet something I never really know or possess until I die, for I am always in the process of inventing it. Identity is something I am rather than have, and yet it is essentially a socially constructed reality ${ }^{8}$. In die verband van hierdie navorsing is belangrik om te vermeld dat hierdie identiteit en gepaardgaande toewyding verhoudingsmatig/relasioneel te verstaan is. Die mens, ook die publieke pastorale leier as mens, beleef identiteit en demonstreer identiteit in die manier wat 'jy' met God, met jouself, met ander, met die werklikheid om jou omgaan. Wanneer daar konstante kontinuïteit ('consistency') in hierdie omgang is, is daar

4 Schner (1933:52-72).

5 Hall (1988:53-79).

$6 \quad$ Schner (1993:63). Vgl. ook sy artikel Schner (1985:94-113). Vgl. ook oor 'personal development for corporate service in the world': Report of the Working Party on Assessment of the Committee for Theological Education. 1987. Education for the Church'c Ministry. London: Advisory Council for the Church's Ministry, 33-34.

7 Schner (1993:80). Vgl. O’Meara (1990:79-103).

$8 \quad$ Schner (1993:84). 
waarskynlik ' $n$ hoë mate van toewyding en 'selfstandige geestelike funksionering,'. Wanneer die mens, gewoonlik gedurende adolessensie, nie daarin slaag om identiteit 'te vind' nie, wreek die gebrek aan identiteit hom op alle ander stadia van ontwikkeling ${ }^{10}$. Om die doel van dit alles ' $n$ oomblik saam met Freeman te sê: 'the realization of true self, God's image individualized'11.

Teologie behoort ' $n$ groot rol te speel in hierdie ontwikkeling van die identiteit van iemand wat in verhoudings leef. Juis daarom is die invalshoek van dissipelskap krities. Binne die verhouding met die Lewende, leer die volgeling en volg die leerling ${ }^{12}$. Hierdie moment het implikasies vir keuring. Schner skryf: 'I will consider ministerial identity as a determination of Christian identity, and that will require consideration of the notions of discipleship, charism, and ordination, ${ }^{13}$.

Farley se besorgdheid is dat 'theology is too much focused on the personal and ecclesial life of the Christian, and not directed to the world'. Hy dink meer fenomenologies en pleit vir ' $n$ verstaan van 'theologia' wat by die verstaan van Aquinas aansluiting vind. Tegelyk vind hy ook aansluiting by Schleiermacher wat ' $n$ saak moes uitmaak vir die huisvesting van teologie aan 'n universiteit. Farley se verstaan van Teologie is wat genoem sou kon word meer klassiek. Hy is op ' $n$ bepaalde wyse in reaksie teen wat hy noem die 'clerical paradigm' as the unifying model or (as) the 'teleological understanding of the unity of theological studies" ${ }^{14}$. Hy bepleit ' $n$ meer reflektiewe wetenskaplike verstaan wat deur die Christen gemeenskap gedeel word oor wie hulle is, wat hulle moet doen, gegewe hulle konkrete wêreld-historiese situasie. Theologia is 'a sapiential knowledge engendered by grace and divine selfdisclosure ${ }^{15}$. Binne die verband van hierdie navorsing vereenselwig

$9 \quad$ Vgl Firet (1977:236).

$10 \quad \mathrm{Vgl} \mathrm{Nel}(2001)$.

11 Freeman (1986:17).

12 Vgl vir verdere lees Schner (1985:94-113); Lindbeck (1988:10-32); Tracy (1988:33-52).

13 Schner (1993:92).

14 Farley (1983:87-88); Vgl Hough \& Cobb (1985:2).

15 Farley (1983:153). 
ek my graag met die kritiek van Hough en Cobb (en ook met die van ander soos Schner). Teologie moet wetenskaplik wees en met akademiese geloofwaardigheid beoefen word, maar Farley se benadering is te abstrak. Dit bied nie " $n$ basis vir die reformasie van teologiese opleiding in belang van die eise van hierdie eeu nie. Terwyl die belangrikheid van die teologie as basis van eenheid vir teologiese opleiding vasgehou word, verminder dit nie die noodsaak vir en in die soeke na teleologiese eenheid nie ${ }^{16}$. Schner meen dat Farley in ' $n$ volgende werk sydelings aan Hough en Cobb se besware aandag gee en verklaar dat opleiding vir die bediening inderdaad teleologies is. Farley bly egter by sy beswaar en sy kritiek dat teologie 'vervang' word met 'pastoral skills" ${ }^{17}$. In baie opsigte is dit natuurlik waar. Dit is inderdaad geen denkbeeldige beswaar nie.

Aan die anderkant lewer Farley inderdaad ' $n$ belangrike bydrae veral ook ten opsigte van persoonlike ontwikkeling as deel van theologia. Banks, in sy paragrawe oor 'the significance of Personal Formation' gee, saam met Strege, krediet aan Farley dat hy ten spyte van die kritiek op sy meer intellektuele benadering 'set the agenda for consideration of moral formation in seminaries ${ }^{\text {, }}$. Vir Farley sluit theologia refleksie op Christelike deugde in, sowel as op simbole en praktyke. Banks, en ander saam met hom, is oortuig dat die habitus wat nodig is, meer is as soos deur Farley beskryf. Volgens hom is meer opleidingsinrigtings oortuig dat geestelike ontwikkeling doelbewus deel moet wees van opleiding: binne en buite die klaskamer. Tereg merk Banks dan op, as verbreding van wat volgens hom die insigte van Farley is, dat 'moral formation should be viewed as simply one dimension of spirituality, involving more than doing the right thing in specific cases. Moral formation concerns a theologically grounded obedience to Christ, and depends on participating in corporate worship, interpreting scripture, and pastoral care ${ }^{19}$.

Schner gebruik as sy invalshoek die vraag wat hierbo vermeld is: is die publieke pastor of, soos ek hierdie persoon nou reeds begin noem het, die publieke pastorale leier professioneel, prakties en

16 Hough \& Cobb (1985:4).

17 Farley (1988:177); Schner (1993:26).

18 Banks (1999:24-28); Strege (1992:113).

19 Banks (1999:26). 
toegewyd. Hy skryf dat hy die woord 'practical' eerder as 'pastoral' gebruik om die debat oor 'pastoral' en 'academic' te vermy ${ }^{20}$. Dit is in hierdie hoofstuk dat hy Hough en Cobb se bedoeling bespreek, naamlik 'the clarification of Christian identity as the basis for Christian practice, ${ }^{21}$.

\subsubsection{J C Hough en J B Cobb}

Hough en Cobb reageer tereg op die ontwikkeling in die VSA, maar waarskynlik ook internasionaal, van ' $n$ burgerstand waar die gemeente nie soseer die karakter van die pastorale leier bepaal het nie, maar die burgerstand. (Heitink verwys sydelings ook hierna wanneer hy telkens verwys na die 'verskille' in die verstaan van die 'amp' in die Hervormde Kerk as kerk van die staat en die gereformeerde kerke as belydenis kerke ${ }^{22}$.) Volgens Hough en Cobb ontwikkel, in lyn hiermee, die verstaan van die 'geleerde figuur' van die 'meester': die een wat opgelei is om te weet ${ }^{23}$. Hierdie noodsaak word radikaal verklein met die koms van baie ander professionele beroepe waarvan ingenieurs eerste was. Hierdie ontwikkeling lei, volgens hulle, tot die teologiese opleiding van 'bouers' - mense wat nog basiese kennis moet hê, maar hulle moet kan bou. Die implikasies is die bemeestering van tegnieke. Die bouer het egter ' $\mathrm{n}$ plan nodig en dit lei tot die verskyning van die 'pastoral director' iemand wat volgens ' $n$ doel bou. Niebuhr speel in hierdie ontwikkeling ' $n$ belangrike rol. Die term 'pastoral director' is ook sy skepping. Hy het gehoop dat ' $n$ konsensus doel vir wat en hoe gebou moet word sal ontwikkel ${ }^{24}$. Soos Hough en Cobb tereg opmerk, het hierdie eenheidsvisie op die kerk nie gekom nie. Alles het eerder meer divers geword. Meer rol verwarring as ooit te vore: 'confusion about the ministry has increased. Reeling under the impact of postneo-orthodox theological criticism and the resulting cacophony of theological voices, and working in congregations with vastly differing expectations, it is little wonder that ministers find no

20 Schner (1993:23).

21 Hough \& Cobb (1985:18); Schner (1993:24).

22 Vgl Heitink (2001:192-193).

23 Hough \& Cobb (1985:5-18).

24 Niebuhr (1956:48,79). 
authoritative basis for their profession, ${ }^{, 25}$. Hierop volg, volgens die outeurs, die opkoms van die bestuurder en die terapeut ${ }^{26}$. Die outeurs vind dan aansluiting by Farley naamlik dat theologia herontdek moet word. Vir hulle beteken dit dan die 'clarification of Christian identity as the basis for Christian practice'. Hierdie identiteit word deur hulle ontwikkel as 'the internal history or memory by which Christians live individually and corporatively. The church is defined by its commitment to keep that memory alive and to express it in present practice. The concern of the seminary must be to help prepare persons who will be able to keep this memory alive and to lead the church to become more of what its memory now calls it to be' $(\mathrm{klem} \mathrm{MN})^{27}$. Later in die boek verwys die outeurs na hulle beskrywing van die kerk as 'being the community whose history has been determined by the memory of Jesus Christ ${ }^{28}$. Watter soort pastorale leier help die gemeente om in alles wat hulle doen getrou te bly aan hulle identiteit as mense wat die herinnering aan Jesus in die samelewing lewend hou? Hough en Cobb noem dit die opkoms van die 'new professional'. Die taak van teologiese opleiding is die die ontwikkeling van 'pathfinders' wat die bedoeling van die gemeente plaaslik en konkreet 'voorsien' ('envision'), maar met sensitiwiteit vir die globale konteks. Hiervoor benodig die kerk 'Practical Christian Thinkers' en 'Reflective Practitioners'. Hierdie persoon word dan deur hulle 'n 'Practical Theologian' genoem ${ }^{29}$. Onder die redaksie van Don Browning verskyn vervolgens ' $n$ publikasie wat hierop respondeer ${ }^{30}$. Binne die verstaan van die identiteit van die gemeente en die verbinding daarvan met die herinnering aan Jesus en hoe die pastorale leiers hierdie herinnering lewend hou, is dit te verstaan dat theologia in hulle geval sterk histories begrond is. Dit is ook sterk missionêr van aard. Leiers word uitgenooi om oor die hele veld van die teologie altyd globaal en Christelik te dink. Belangrik is hulle opmerking dat wanneer spesiale kursusse bygevoeg word die fokus op Christelike dissipelskap eerder

25 Hough \& Cobb (1985:15).

26 Vgl McIntyre (1981:26).

27 Hough \& Cobb (1985:18).

28 Hough \& Cobb (1985:76).

29 Hough \& Cobb (1985:100).

30 Vgl Browning, Polk \& Evison (1989). 
as spiritualiteit moet wees. Hulle is myns insiens in die kol met die opmerking dat wanneer spiritualiteit geskei word van die konteks van dissipelskap lei dit na alle waarskynlikheid tot ' $n$ verskraalde verstaan van spiritualiteit ${ }^{31}$. Juis dit kan die kerk nie nou bekostig nie.

Samevattend kom die standpunt van die outeurs neer op die opleiding van persone wat teologies op die praxis kan reflekteer. Hulle is reg in hulle kritiek dat dit teenoor die populêre verstaan van 'professioneel' staan. Dit gaan nie om die toepassing van teorie om probleme op te los nie. Bediening is in meer as een opsig teologiese reflektering op die praktyk. Juis dit kan (en moet) verbeter word. Pastorale leiers behoort vir hulleself die paradigma van 'reflective practitioner' te aanvaar ${ }^{32}$. Ek wil vir geen oomblik betrokke raak in ' $n$ futiele argument 'dat die vak Praktiese Teologie die belangrikste vak in teologiese opleiding is' nie. Dit is ook nie die argument van die outeurs onder bespreking nie. Die belangrike is die beklemtoning dat pastorale leiers in staat moet wees om teologies nie alleen oor die praktyk nie, maar in die praktyk na te dink (reflekteer) ${ }^{33}$. Soms word dit eenvoudig 'teologiese wysheid' genoem ${ }^{34}$. Dit is wel waar dat dit ook die metodologiese eie van die vak Praktiese Teologie is. Die punt hier is egter van meer kardinale belang as net die metodologie van ' $n$ teologiese dissipline (hoe belangrik dit ook al op sigself is $)^{35}$. Tereg beklemtoon Hough en Cobb dat om oor en in die praktyk te reflekteer vir alle Christene geld. Die verskil is dat publieke pastorale leiers dit hoofsaaklik in die kerk doen. Hulle verstaan van die kerk is daarom krities. Hulle moet daarom in staat wees om mede gelowiges te help om hulle Christelike identiteit te ontwikkel en verstaan 'so that together they may act in a Christian way $^{36}$.

31 Hough \& Cobb (1985:115-116); Vgl ook Banks (1999:73-128).

32 Hough en Cobb kry die term by Schoen (1983).

33 Hough \& Cobb (1985:84-85).

34 Banks (1999:19).

35 Vgl o a Pieterse (1993); Heitink (1993 \& 1999). Vir Hough en Cobb se eie verstaan van 'The Practical Theologian', vgl Hough \& Cobb (1985:90-94).

36 Hough \& Cobb (1985:84). 


\subsubsection{M Wood}

Die bydrae van Wood vind hierby aansluiting. Hy pleit naamlik vir teologie as 'critical inquiry", Volgens hom is teologiese opleiding streng gesproke die proses waardeur 'persons acquire an aptitude for theology. An aptitude for Christian theology is a capacity and disposition to engage in critical reflection upon the Christian witness (which means, upon what is conveyed by everything that Christians are, say, and do as Christians, singly and together), ${ }^{38}$. In die verband van hierdie navorsing is Wood se bydrae krities. Hy beskou theoria as die eeu oue vennoot van 'vision'. Saam hiermee gaan 'discernment': 'If vision sees the totality, discernment is the grasp of the individual; the interpretation of differences; discrimination, rather than synthesis ${ }^{39}$. In die teologiese opleiding is albei krities. Visie het te doen met die omvattende, 'the quest for a coherent understanding of the Christian witness as a whole'. Oor die algemeen word soms hierna verwys as teoretiese denke. Onderskeiding is die teologiese poging 'to grasp and assess the character of a particular instance in Christian witness -past, present, or prospective. Discernment probes the actual logic of witness, to discover how, in fact, its concepts and assertions do function, ${ }^{40}$. Later in die boek noem hy die algemene opvatting dat teologiese opleiding studente moet toerus met 'a body of objective knowledge' ' $\mathrm{n}$ 'powerful half-truth'. Sy punt is nie dat dit onbelangrik is nie, maar wel onvolledig: "It is not the mere possession of "a theology" that is the measure of a theological education; it is rather one's ability to form, revise, and employ theological judgements that counts. Vision and discernment are exhibited in practice ${ }^{41}$. Sy pleit is geldig: teologiese opleiding vra nie net (en het nie net dit ten doel nie) die 'vorming van oordeel' nie; dit vra nie net 'spiritual formation' nie. Hierdie sake is belangrik, maar is nie genoeg nie. Sy betoog is vir 'iets' wat hierdie sake in verband bring en in verhouding plaas tot die groter geheel van 'visie en onderskeiding'.

37 Wood (1985:21-35). Vgl ook Luck (1999:121-130) vir sy verstaan van die ontwikkeling van kritiese denke.

38 Wood (1994:15).

39 Wood (1985:67-68).

40 Wood (1985:73-74).

41 Wood (1985:82). 
Dit noem hy dan die ontwikkeling van kritiese denke en kritiese navraag ('critical inquiry'). Hy wys daarop dat 'Christian formation' en 'critical inquiry' dikwels in die tradisies van sowel die 'katolieke' en 'evangeliese kerke' as onversoenbaar beskou is. Laasgenoemde sou dan in die teologie bots met vroomheid en nederigheid. Hy gebruik ' $n$ sterk teologiese argument waarom dit nie so is nie: hoewel dit in ander wetenskappe wel so is dat kritiese distansie gevra word in die bestudering van die vakinhoude 'in theology, at least, understanding follows commitment ${ }^{42}$. Sy aanhaling uit ' $n$ vertaling van Anselmus is hier nie net mooi nie, maar krities vir die navorsing onder bespreking: 'For I do not seek to understand that I may believe, but I believe in order to understand. For this also I believe, - that unless I believed, I should not understand ${ }^{43}$. Wood gaan direk voort om te sê: 'The route to theological understanding, it is said, is not criticism, but faith ${ }^{44}$.

Aan die einde van sy boek kom hy nog ' $n$ maal terug daarop dat teologiese opleiding meer is as om maar net take in die bediening 'professioneel' te kan verrig. Binne sy verruimde verstaan van wat dit is, vat hy dit so saam: 'theological education is not necessarily professional education for ministry, but the heart of proper professional education for ministry is theological education meaning by 'theological education' an education in theological inquiry. One may properly seek and obtain a theological education without any intention of preparing for church leadership of any sort; but one may not properly prepare for church leadership without acquiring theological competence'(beklemtoning $\mathrm{MN})^{45}$. Dit gaan om meer as korrekte uitvoering van take. Farley is waarskynlik reg wanneer hy skryf dat hoe meer die uitvoering van take die fokus en telos van teologiese opleiding word, 'the less the minister becomes qualified to carry them out ${ }^{46}$.

Samevattend kom Wood se pleit neer op die ontwikkeling van visie en onderskeidingsvermoë. Hierdie twee sake vra: 'intelligence,

42 Wood (1985:84-85).

43 St Anselm (1958:7). Aangehaal deur Wood (1985:85).

44 Wood (1985:85).

45 Wood (1985:93).

46 Farley (1983:128). 
sensitivity, imagination, and a readiness to deal with the unforseen, ${ }^{, 4}$. Of soos Hough en Cobb in aansluiting by Schoen dit stel: 'reflective action is always open for surprise" ${ }^{48}$. Wood verwys in sy opvolg werk na ' $n$ artikel van Kant waarin hy die onvolwassenheid waarbinne ons 'veragter' ('languish') beskryf as 'the incapacity to use one's intelligence without the guidance of another' ${ }^{49}$. Hoe ons dit ook al formuleer, skryf Wood, 'most crucial to the overall function of leadership is the leader's capacity to think with and on behalf of the tradition". Dit beteken beslis dat so iemand dan die tradisie van die Christelike getuienis grondig moes bemeester en aan die ander kant die vermoë moet besit en ontwikkel om ' $n$ kritiese afstand tot die tradisie te behou ${ }^{50}$. Openheid hou uiteraard verband met identiteit ${ }^{51}$.

\subsubsection{G Heitink}

Uit die werk van Heitink, waarna reeds verskeie kere verwys is, kan baie afgelei word oor die belang van teologie in die lewe van die pastorale begeleier of soos hy dit noem 'leiding als pastorale dienst $^{52}$. Die momente waarna ek graag hier verwys en wat direk relevant is vir hierdie navorsing kom neer op wat hy noem die 'agogisering van het pastorale beroep' solank dit maar in diens staan van die 'toerusting van gemeentenleden, erop gerig om de functies van het ambt in toenemende mate om te bouwen tot functies van de gemeente ${ }^{53}$. Hierdie insig is krities. Wie die uitgangspunt in hierdie navorsing verstaan en ondersteun, weet dit: die gemeente is die draer van die bedoelinge van God; die gemeente is ingeskakel by die skeppende en heelmakende aktiwiteite waarmee God in elk geval in hierdie wêreld besig is; aan hierdie gemeente skenk God persone om die gemeente vir dienswerk bekwaam te maak of toe te rus, of, soos Heitink met verwysing na Firet en Berkhof skryf 'om die identiteit

47 Wood (1985:94).

48 Hough \& Cobb (1985:89). Vgl Schoen (1983:295, 296, 328).

49 Friedrich (1949:132); Wood (1994:36).

$50 \quad$ Wood (1994:28).

51 Vgl Hess (1991:104-214).

52 Heitink (2001:273).

53 Heitink (2001:269). 
van die gemeente te bewaak ${ }^{, 54}$. Wanneer hierdie verstaan van die gemeente goed gevestig is, verander die rol van 'die lerende enkeling' in die lerende gemeente opvallend. In Nederland word in 2000 ' $\mathrm{n}$ hele uitgawe van Praktische Theologie aan hierdie tema gewy. Die tema nommer verskyn onder die opskrif 'Laat u geen meester noemen ${ }^{, 55}$.

Heitink skryf vervolgens dat dit gaan om integrasie van wat hy noem 'de drie in een vorm van pastorale leiderschap dat geloofwaardig, dienstvaardig en hoogwaardig' genoem kan word. Hy pleit dan vir ' $n$ ander manier van organisering van die 'predikantschap' met meer aandag vir 'specialisatie, differentiatie, teamwork en loopbaanontwikkeling ${ }^{56}$. Dit is in die uitwerk van hierdie gedagte lyn dat hy pleit vir die nuwe verstaan en noodsaak van die 'open kerk' ${ }^{57}$. In sy argument vir 'gematigde spesialisasie' bespreek hy dan 'n saak wat vir die argument in hierdie navorsing radikaal belangrik is. Hy argumenteer vir ' $\mathrm{n}$ kern deskundigheid by die pastorale leier. Hierdie kern deskundigheid omskryf hy dan as 'hermeneutisch-communicatieve competentie'. Dit is volgens hom hier waar die Praktiese Teologie ' $n$ tree verder gee as die ander teologiese dissiplines. Sonder enige direkte verwysing na die werk van Van der Ven vind hy aansluiting by hom en skryf: "Zij legt in het hermeneutisch proces de nadruk op de verbinding van kennis, inzicht, vaardigheden en attitudes' wat in verhouding tot mekaar die pastorale leier met die oog op sy persoon, amp en beroep geskik en bekwaam maak om as tolk te kan optree in die kommunikasie proses waarin hy of sy betrokke raak (laaste deel van die sin vry vertaal $\mathrm{MN})^{58}$. Dit word onverhandelbaar in die opleiding van ' $\mathrm{n}$ 'basispastor'. Gematigde spesialisasie beteken vir hom dat die beroep ' $\mathrm{n}$ kern het wat alle spesialisasie deurtrek (soos water ' $\mathrm{n}$ spons $\mathrm{MN}$ ). Hierop voortbouend betoog hy dan dat veral in drie

54 Heitink (2001:273).

55 Vgl. veral Hendriks \& Jonker (2000:135-156); Heitink (2000:223-230).

56 Heitink (2001:270-271).

57 Die behoeftes wat so ' $n$ verstaan van die kerk noodsaak is volgens hom o.a. singewing, informasie, ritualisering, behoeftes van diakonale aard en gasvryheid, vgl Heitink (2001:280).

58 Heitink (2001:284). Vgl Van der Ven (1998:153). Heitink se verwysing is na Van der Ven (2000). 
rigtings vir spesialisering voorsiening gemaak word: die 'pastorale' rigting, die 'educatieve' rigting en die 'opbouwkundige' rigting ${ }^{59}$. In die verband van loopbaan perspektief argumenteer hy vir ontwikkeling binne spanverband. Oorvereenvoudig kom dit neer op: van 'junior-predikantskap', van 'deeltaakfunctie' tot senior-predikant , tot 'bovenplaatselijk ambtsdrager' in die rol van pastor pastorum, ' $n$ vertrouenspersoon en spanleier ${ }^{60}$. Hoe moeilik en sensitief ook al kerke sal meer moet doen aan voortdurende 'beroep-toetsing' ten einde in bogenoemde sin mee te werk aan gesonde loopbaanontwikkeling. Literatuur hieroor is baie en die bestudering van die saak self vorm nie deel van hierdie navorsing nie. Die noodsaak daarvan word hier bepleit en gestel ${ }^{61}$.

\subsubsection{J A van der Ven}

Van der Ven se bydrae ten opsigte van opleiding vir 'reflective ministry' is in die verband van hierdie navorsing van besondere belang. Ek wil graag nog ' $n$ maal hierna terugkom. Sy 'invalshoek' is eweneens die geweldige komplekse aard van godsdiens in die samelewing. Hy verwys na 'differential secularization, in the sense that religion can be observed to exert a variety of influences within the various societal systems...which sometimes reinforce and at other times contradict each other' ${ }^{62}$. Hierdie komplekse aard van die godsdiens, die kerk op mikro-, meso- en makro vlak vra na nuwe denke. Volgens hom lyk dit of die twee modelle wat tot 1960 en selfs daarna teologiese 'skole' gekenmerk het nie meer die behoeftes van die tyd ontmoet nie naamlik die kerugmatiese en kerklike ('ecclesial') modelle. Onder andere as gevolg van navorsing in die sosiale wetenskappe en empiriese navorsing is hulle vervang of ten minste aangevul met wat hy noem die 'therapeutic model and the managerial model ${ }^{63}$. Sy oortuiging is dat ons moet soek na iets wat die bestuursbenadering in ag neem, maar wat verder gaan. Om in hierdie komplekse wêreld pastorale leier te wees, vra na goeie

59 Heitink (2001:284).

60 Heitink (2001:288).

61 Vgl Klimoski (2003:35-52). Vgl ook die besondere belangrike proefskrif van Brouwer (1995) vir 'n omvattende navorsing oor 'professionalisering' van die predikantskap.

62 Van der Ven (1998:43).

63 Van der Ven (1998:82-83). 
basiese opleiding ('general competent reflection in ministry') en wat hy noem 'special competent reflection in ministry' ${ }^{64}$ Van der Ven verwys ook na die sentrale rol wat 'the epistemology of technical rationality' in die bestuursmodel speel. Volgens Carroll is dit juis ook die swakheid van die professionele model of, in Van der Ven se verwysing, die bestuursmodel ${ }^{65}$. Hierdie rassionaliteit is nie sentraal in die reflektiewe bedieningsmodel nie. "Rather, the central focus is on the idea of practical, rationality-based self-responsibility and selfdirection.... What the pastor must learn, and what the education for ministry program must lay the foundation for, is to develop the professional competence to deal adequately with problematic situations, to discover, formulate and analyze the religious problems contained therein, to use the basic tools to consider and weigh alternative solutions, to arrive at judgements while experimenting, and to reach decisions while acting' - alles terwyl die persoon besef dat daar altyd nuwe situasies sal wees wat vra na nuwe refleksie. Vir hierdie refleksie is kennis van vorige probleme en hulle oplossings in samewerking met ander professionele persone en die lidmate nodig $^{66}$. In die ontwikkeling van ' $n$ raamwerk vir die verstaan van die omvang van so " $n$ reflektiewe bediening beskryf Van der Ven dan, wat ek sou noem en wat hy ook noem, die identiteit van die kerk. Hy beskryf dit onder drie hoofde naamlik die visie van die kerk wat die identiteit 'as the people of God' behels, die missie van die kerk 'as the movement of Jesus', en 'imagination' as 'the church as a community of the Spirit' ${ }^{67}$. Wat is binne die komplekse aard van die samelewing, die rol van godsdiens in hierdie samelewing en die steeds nuwe eise van die bediening nodig om ' $\mathrm{n}$ 'basispastor' op te lei? Weliswaar voor Heitink skryf hy: 'hermeneutic communication functions as the common denominator of the seven special functions ${ }^{68}$. Kompetente pastorale leiers het kennis, insig, vaardighede en houdings ('attitudes') nodig. Van der Ven bedoel, kortliks opgesom, hiermee die volgende:

64 Van der Ven (1998:156-157).

65 Carroll (1985:17).

66 Van der Ven (1998:85).

67 Van der Ven (1998:100-116).

68 Van der Ven (1998:123); Vgl Hetink (2001:284). 
* Kennis verwys na die vermoë 'to reproduce narratively and conceptually structured information';

* Insig verwys na die vermoë 'to produce narratively and conceptually structured information' (Kennis het te doen met reproduksie van inligting en insig met die produksie van inligting (Van der Ven vry vertaal MN);

* Vaardighede verwys na die vermoë 'to appropriately use social methods and techniques which apply to specific aspects of concrete situations in which the professional performs his work';

* Houding het te doen met 'the affective-evaluative orientations which the professional has at his or her disposal in order to perform his or her work in an appropriate way. 'Orientation' refers to the particular style or manner in which the person relates to persons or things'. In hierdie oriëntasies speel gevoel ' $n$ rol en vandaar die begrip 'affective" ${ }^{69}$. Binne hierdie komponente van kompetensie moet pastorale leiers algemene refleksie en spesifieke refleksie vaardighede ontwikkel. In my eie woorde sou ek sê dat die pastorale leier teologies moet kan reflekteer op die bediening in die sin van kennis, insig, vaardigheid en houding ten opsigte van wat ek doen, waarom ek dit só doen, hoe ek dit doen en in watter gesindheid (of met watter houding) ek dit doen.

'n Opmerking van Petersen, wat drie jaar na Van der Ven skryf, is hier van belang: teologie is die gewete van die kerk $^{70}$. Alle lidmate is geroep tot ' $n$ bepaalde mate van teologiese geletterdheid. Wat van die publieke pastorale leier gevra word, is om die geloofsgemeenskap tot hierdie 'geletterdheid' te lei. Hiervoor is bogenoemde soos deur Van der Ven benaam, nodig. Tracy voeg ' $n$ belangrike perspektief by wanneer hy skryf dat van enige geloofsgemeenskap verwag kan word om ' $n$ community of inquiry' (of ' $n$ reflekterende gemeenskap) te wees. Die vraag is dan of ' $n$ gemeenskap wat navraag doen (vrae vra) en selfs bevraagteken ook tegelyk ' $n$ gemeenskap van geloof en verbintenis kan wees? Tracy verbind dan die klassieke uitdrukking wat aan Socrates gekoppel word met ' $n$ Boeddistiese spreuk: 'The unreflective life is not worth living' en

69 Van der Ven (1998:152-160).

70 Petersen (2002:1-12). 
'The unlived life is not worth reflecting upon' ${ }^{, 71}$. Volgens hom is dit juis die unieke bydrae van die teologie, want in die teologie 'action and thought, academy and church, faith and reason, the community of inquiry and the community of commitment and faith are most explicitly and systematically brought together, ${ }^{72}$. In lyn met die argumente van Van der Ven spreek hy sy oortuiging uit dat die Westerse kultuur skade gely het deur die drie groothede wat ons lewe van refleksie dryf, te skei, naamlik ons ideale, ons hoop en ons liefde. Hierdie drie 'fatal separations' noem hy:

* 'the separation of feeling and thought;

* the separation of form and content;

* the separation of theory and practice, ${ }^{73}$.

\subsubsection{Behoud van kompetensie}

Dit is deel van die teleologiese perspektief op teologiese opleiding dat publieke pastorale leiers opgelei, en in die sin kompetent, bly. Wanneer die beoefening van die teologie soos hierbo beskryf in belang van die gemeente gebeur, is dit logies: die gemeente en die voortdurende opleiding van die gemeente vereis die voortgesette opleiding van die pastorale leiers. Wright is myns insiens korrek wanneer hy skryf dat '(we need to) knead out the knots through a commitment to learning. Great leaders make a commitment to ongoing learning, ${ }^{74}$. Dit word in enige ander beroep aanvaar, waarom nie ook in hierdie 'noble task' (Kalthoff) nie? My verwysings hierbo na die eise in hierdie bediening onder bespreking bevestig die noodsaak van voortdurende ondersteuning ook en veral deur voortgesette opleiding. In die Lutherse tradisie word nou nog meermale sterk aangesluit by perspektiewe wat tot op Luther teruggaan. In die voorwoord tot die Kleine Kategismus skryf hy: 'Our office...involves much fatigue, danger and temptation...little reward and gratitude from the world. But Christ Himself wants to be our reward, if we work in truthfulness ${ }^{75}$. Bishop Diethardt Roth in

71 Tracy (2002:13-22).

72 Tracy (2002:15).

73 Tracy (2002:15).

74 Wright (1999:26).

75 Aangehaal deur Leopoldo Heimann in Joerz \& McCain (1988:167). 
sy repliek op dieselfde referaat van Kalthoff verwys ook na Luther se drie 'dinge' wat 'n teoloog maak naamlik 'oratio, meditatio, tentatio (prayer, meditation and spiritual struggle)'. Hy gaan voort en beklemtoon dat vir hierdie werk sowel die teoloog as die lidmaat goeie teologiese opleiding nodig het. Die pastorale leiers het vandag in die volgende areas meer kompetensie nodig: 'theologicalhermeneutical, context-analytical, mission-pastoral, personalspiritual and dialog-self critical ${ }^{76}$.

Argumente waarom dit lewensbelangrik is vir pastorale leiers wat nou in die publieke bediening inkom, geld net so en nog meer vir hulle wat reeds in hierdie bediening is. Om weer by Carroll en ook by Hough en Cobb aan te sluit: om vir en ook namens die gemeente 'reflective practitioner' te bly, iemand wat net nie net oor die praktyk dink nie, maar iemand wat in praktyk dink, vra na voortdurende opleiding in die praktiese teologie. Hough en Cobb noem hulle 'Practical Christian Thinkers" ${ }^{\text {,7 }}$. Denkende dominees en nie maar iemand wat ' $n$ 'practitioner' per se word nie. Dit kan selfs grens aan ewolusionêre aanpassing in " $n$ praktyk waarin so iemand nie meer dink nie, maar leer oorleef. Ons benodig almal teologiese opleiding wat hoe langer hoe meer verruim en 'is meant to improve your theological judgement. Its purpose is to make you better at recognizing valid Christian witness should you happen across any; to spot the bad stuff too - the inauthentic, unintelligible, inept stuff that, sad to say, abounds - and furthermore to see what is wrong with it; and to subject not only others' but also (and perhaps foremost) your own past and prospective efforts at witness and at the leadership of witness to searching, constructive criticism, ${ }^{78}$. Wood merk op dat dit nie die 'besit' van 'n teologie is wat tel nie, maar iemand se vermoë om self teologiese oordeel te ontwikkel, te evalueer, te hersien en te gebruik. Binne die tema van sy werk word 'visie en onderskeidingsvermoë' só ontwikkel en onderhou ${ }^{79}$. In 'n publikasie van die Mennoniete word dit so gestel: 'As a disciplined way of

76 Roth in Joerz \& McCain $(1998: 171,174)$. Vgl ook Scharlemann wat in aansluiting van die uitganspunt van Luther handel oor vocatio, oratio, meditatio, tentatio, renovatio, in Lieske (1984).

77 Carroll (1986:14); Hough \& Cobb (1985:84-85).

78 Wood (1994:5).

79 Wood (1985:82). 
thinking, theology seeks to bring coherence, consistency, insight, and intellectual rigor to both the critical and the constructive tasks of the church's teaching ministry ${ }^{, 80}$.

Kew en White se argument om teologiese opleiding nuut te bedink vanuit die 'global mission' van die kerk (of moet dit wees: vanuit die kerk as 'global mission' $M N$ ) beklemtoon van 'n ander kant die belang van voortgesette opleiding. Dit is nodig om publieke pastorale leiers te bewaar daarvan om die 'CEO of a 'religious bus' te wees; om nie vasgevang te word in die oorlewing van godsdienstige klubs nie, maar om dinamies, 'beyond survival' en 'chief evangelist, teacher, and pastor' deel te wees van 'n gemeente wie se teologiese identiteit hulle help om te onthou 'what business we are in ${ }^{, 81}$. Voortgesette opleiding is nodig om ' $n$ vars visie op die missie van die gemeente wakker te hou. Die hermeneutiese vermoëns en vaardighede van publieke pastorale leiers word in voortgesette opleiding opgeskerp ${ }^{82}$. Hierdie persone moet immers kompetent bly '(to reduce) high-voltage academic theology to insight and perspective that can shape the lives of the people touched by their ministries ${ }^{83}$. Carroll skryf tereg dat ' $n$ hoë vlak van knapheid ('expertise') in teologiese refleksie en visionering in hierdie beroep nodig is. Leierskap is nodig ten opsigte van betekenisgewing, hermeneuse, as gemeenskap bouers, 'and, for a lack of a better term, as managers of the interface between the church and its social context ${ }^{84}$.

Die doel van hierdie navorsing is nie om voortgesette opleiding as sodanig te beredeneer nie. Die saak is egter wesenlik tot die tema. ' $n$ Argument wat soms in die motivering vir voortgesette opleiding nie genoegsaam figureer nie is die waarde daarvan vir die individu self. Ek volstaan in hierdie verband met ' $n$ opmerking wat Mark Rouch reeds in 1974 skryf: 'Continuing Education is an individual's personally designed learning program which begins when basic formal education ends and continues throughout a career and

80 Associated Mennonite Biblical Seminary (1994:6).

81 Kew \& White (1997:105).

82 Vgl Schner (1993:71, 170-171).

83 Luck (1999:90).

84 Carroll (1986:18, 22). 
beyond. An unfolding process, it links together personal study and reflection and participation in organized group events... Lifelong learning is that quality of life characterized by openness to oneself, to others, and to the world which lets learning occur anytime, anywhere, using whatever data may be available and appropriate'. Dit lei tot 'competence and effectiveness ${ }^{, 85}$.

\subsubsection{Samevattend}

Vir die doel van hierdie navorsing, is die volgende van belang:

* Teologie is meer as informasie oor teologiese dissiplines soos wat dit histories ontwikkel het. Dit is meer as toetsbare en getoetsde kennis van 'vakke'. Daar behoort meer te wees as inhoudelike eenheid. Die situasie vra na ' $n$ teleologiese eenhiedsprinsipe. Hierdie teleologiese integrasiepunt is onder meer die bediening van die pastorale leier. Om dit weer ' $n$ keer saam met Wood te sê: 'One may properly seek and obtain a theological education without any intention of preparing for church leadership of any sort; but one may not properly prepare for church leadership without acquiring theological competence'(beklemtoning $\mathrm{MN})^{86}$. Opleiding vir die publieke bediening van pastorale leiers vereis teologie, teleologies verstaan.

* Die ontwikkeling van die vermoë om teologies te reflekteer op teorie en praxis is krities in teologiese opleiding. Dit is ' $n$ kognitiewe vermoë. Kritiese denke soos hierbo beskryf, is vir die funksionering van die gemeente en die inskakeling van die gemeente by die skeppende en heelmakende aktiwiteit van God belangrik. Die gemeente se identiteit vra na pastorale leiers wat kompetent en kreatief die identiteit van die gemeente bewaak $^{87}$. Ek beweer nie dat alle teologiese studente intellektueel hoog moet meet nie. Dit is egter onteenseglik waar dat kognitiewe ontwikkeling verband hou met intelligensie. Dit is nie hier die plek om dit te beredeneer nie. Uit die literatuur, waarvan hier maar ' $n$ seleksie aangehaal is, is dit nie moeilik om af te lei dat wat in teologiese opleiding in lyn met die behoeftes van die bediening gevra word, vereis ' $\mathrm{n}$ hoë vlak van kognitiewe vermoëns. Juis hier lê ' $\mathrm{n}$ sensitiewe probleem. Wat hier

85 Rouch (1974:16-17, 29, 33).

86 Wood (1985:119); Vgl ook MacInnis (2002:382-391).

87 Hetink (2001:273). 
in kerk kringe selfs soms net nog gefluister word, word deur Katarina Schuth op grond van ' $n$ empiriese studie (wat 550 individuele onderhoude ingesluit het) so verwoord: 'Compared with ten years ago, most faculties report that they are teaching about the same small number of excellent students and that the broad middle range of students also remains steady. The difference appears at the lower end of the spectrum: many faculties believe that the least gifted students are weaker now than ever before ${ }^{88}$. In die studie word uiteindelik onderskei tussen drie groepe studente: 'most highly qualified, relatively qualified and insufficiently qualified students'. Self in die geval van die relatief gekwalifiseerde groep is bevind dat 'even the brighter ones tend not to be readers, and they lack the broad cultural foundation afforded by a study of the classics. Their appreciation of language and the imagination necessary to enter into the world of theology is underdeveloped, while they also lack the historical consciousness required for understanding the evolving church. Faculties are faced with the task of inspiring these students to acquire a thirst for knowledge, to be more inquisitive and creative $^{89}$. Schuth is korrek in haar opmerking dat die intellektuele eise vir die bediening vandag buitengewoon hoog is. " $n$ Meer en beter opgevoede en opgeleide kerkgemeenskap eis eenvoudig goed opgeleide publieke pastorale leierskap ${ }^{90}$. Intellek is beslis nie alles nie, maar wat wel waar is, is dat iemand wat intellektueel swaarkry waarskynlik ander maniere om te oorleef moet vind. Sommige dink dat die enigste uitweg dan aggressie en outoritêre houdings is. Dit impakteer ook op verhoudingsvaardighede en laasgenoemde is juis krities vir publieke pastorale leiers ${ }^{91}$. In ' $n$ deeglike verslag van die Evangelical Lutheran Church in Amerika word onomwonde gestel: 'the applicant should possess intellectual ability for critical and reflective thinking', ${ }^{92}$. In ' $\mathrm{n}$ ander baie omvattende stuk navorsing word gewerk met die begrip 'fitness for preparation and engagement in the practice of effective professional ministry'. Dit word vervolgens beskryf as: ... potential to become an effective minister.

88 Schuth (1999:80).

89 Schuth (1999:81-82).

90 Schuth (1999:79).

91 Schuth (1999:87).

92 Evangelical Lutheran Church in America (1995:9). 
Potential includes all dimensions that contribute to this outcome, such as intellectual ability, personal structure, interpersonal styles, accuracy and appropriateness of self-image, interests, motivation, and uses of social support networks ${ }^{, 93}$.

* Teologiese refleksie vereis hermeneuties-kommunikatiewe vermoë. Die pastorale leier is inderdaad pont roeier ${ }^{94}$ wat heen en weer roei tussen die Christelike tradisie en nou, tussen groep en groep, individu en individu. In die taal van Van der Ven funksioneer die pastorale leier altyd op makrovlak (gemeenskap), mesovlak (gemeente) en mikrovlak (individu) ${ }^{95}$. Die pastorale leier is kommunikeerder. Hiervoor het hy of sy hermeneutiese vermoëns nodig. Wie nie met die verlede kan kommunikeer nie, wie die teks van die Bybel en die tweede teks van samelewing, gemeente en persone nie kan lees en interpreteer nie, kan nie publieke pastorale leier wees nie.

* Direk in verband met die voorafgaande is die vermoë om holisties te dink en te kan onderskei. 'Vision and discernment ${ }^{96}$ het alles met die verstaan van die telos van opleiding en die roeping tot publieke pastorale leiding te doen. Reeds in 1979 skryf Costas dat die grootste toets vir die missionêre verstaan van kerkwees is 'not whether we proclaim, make disciples, or engage in social, economic and political liberation but whether we are capable of integrating all three in comprehension, dynamic and consistent witness' (beklemtoning $\mathrm{MN})^{97}$.

* Kern deskundigheid, die vorming van 'n 'basispastor' (Heitink), is onverhandelbaar. So ook is gefokusde en gedifferensieerde spesialisering, of soos Heitink dit noem, 'gematigde spesialisering'. Die gemeente het dit nodig vir sy opleiding om die bedoeling van God in ' $n$ komplekse en diverse wêreld te verwerklik.

93 Hunt, Hinkle \& Malony (1990:13).

94 Heitink (2001:284).

95 Van der Ven (1998:130).

96 Wood (1985).

97 Costas (nd:75). Vgl ook my eie verstaan van Gemeentebou as die integrering en koördinering van alle bediening in belang van die kommunikasie van die evangelie van die Koninkryk van God (Nel 2004:54). 
* Pastorale leierskap moet tegelyk professioneel, prakties en 'devoted' wees ${ }^{98}$. Professioneel in die sin van kompetent om hierdie publieke bediening met trots en grasie te vervul, prakties in die sin van in staat om teologies te reflekteer ('doctrinal clarity, as well as historical accuracy and contextual inventiveness') ${ }^{99}$, en 'toegewyd' in die sin van geestelik gevormd. Die invalshoek vir laasgenoemde kan en behoort die van dissipelskap en dissipelmaking te wees. Hierdie kern begrip hou verband met die kern deskundigheid en kern vaardigheid van die pastorale leier op alle vlakke van die bediening. Dit bring weer eens die fokus op die didache na vore ${ }^{100}$.

* ' $\quad$ 'n Herontdekking van wie 'ons' is, is dringend nodig. 'n Nuwe houding as pastorale leier en verstaan van die identiteit is krities. Heitink sê tereg dat sy benadering nugterder is, maar verwys wel na die postmoderne kultuur se verwagting dat 'die pastor van die toekoms is die een wat ophou om pastor te wees' ${ }^{101}$. Daar is waarheid hierin. Peterson het waarheid beet wanneer hy argumenteer vir ' $n$ gesindheid van 'onnodig' te wees. Dienaars weet dit. Dit vra na ' $n$ radikale bekering van publieke pastorale leiers wat diens lewer tot dienaars wie se bediening publieke pastorale leiers is ${ }^{102}$.

* Voortgesette teologiese opleiding is onverhandelbaar en onmisbaar noodsaaklik en belangrik. Almal het dit nodig om kompetent te bly. In ' $n$ ongepubliseerde referaat vat Anderson die redes vir hierdie opleiding saam as die voortdurende en toenemende verandering in die samelewing, die kontekstuele karakter van die teologie in beide teorie en praktyk en die gepaardgaande 'leer in konteks', die feit dat teologiese opleiding nie eindig met die formele opleiding in fakulteite nie en dat dit nie net teologiese professore is wat persone vir die publieke pastorale leierskap oplei nie. Hy maak hierdie opmerkings by wat genoem word 'first-call theological education' binne die Lutherse denominasie. Dit raak naamlik die noodsaak van voortgesette opleiding binne die eerste drie jaar na

$98 \quad$ Vgl weer Schner (1993:xiii).

99 Schner (1993:23-51); Vgl weer Van der Ven (1998:85).

100 Vgl Luck (1999:63). Hy merk tereg op dat die kerk se verwagting dat geordendes teologies opgelei moet wees teruggaan na die rabbynse tradisie.

101 Heitink (2001:255).

102 Vgl Dawn \& Peterson (2000:1-20). 
bevestiging. Die doel is veelvoudig, maar veral om te help met die oorgang na die gemeente, met kontekstualisering, met teologiese refleksie en integrering van die teologiese dissiplines in die bediening ${ }^{103}$. In die twaalf 'imperatives for theological education' soos deur die Evangelical Lutheran Church in America verwoord, word in die sewende imperatief gestel: 'Because of the changing, diverse context of our mission, it is necessary that leaders continually grow in faith, expand their skills and increase knowledge through continuing education... While it is expected of all pastors...it is certainly needed during the early, formative years of ministry in a specific context...The church must encourage and provide resources for its leaders to continually develop and renew their gifts for ministry through disciplined patterns of life-long learning, ${ }^{104}$.

* In die goeie artikel van Van Nijen vat hy die bevinding van sy onderhoude soos volg saam (vry vertaal uit die Nederlands MN): " $n$ Kompotente voorganger verenig in hom/haarself ' $n$ meerdere of mindere mate vyf dimensies van kompetensie:

* Individuele dimensie - persoonlikheid en geskiktheid;

* Akademiese dimensie - deskundigheid en bekwaamheid;

* Tegniese dimensie - vaardigheid en geskiktheid;

* Spirituele dimensie - innerlikheid en betrokkenheid;

* Kerklike dimensie - bevoegdheid en verantwoordelikheid ${ }^{105}$.

\subsection{Werwing, keuring en teologiese opleiding}

\subsubsection{Die gemeente in werwing en keuring}

Binne die verband van hierdie navorsing is nou reeds meermale geredeneer in belang van die plaaslike gemeente. In die herontdekking van roeping tot die publieke pastorale leierskap is dit belangrik om te verstaan dat die gemeente nie die eerste stap op " $n$ leer van beroepsontwikkeling is nie. Dit is nie soos klerkskap in " $n$ klein bank iewers op die platteland, voordat jy vir ' $n$ 'volgende grootte bank' in aanmerking kom nie. Elke gemeente is volledig in die sin van ingeskakel by die basiese kontekstuele bedoeling van God. Geen

103 Anderson (2003).

104 Evangelical Lutheran Church (1995:29).

105 Van Nijen (1995:229); Vgl ook Heitink (2001:226). 
stukkie van God se aarde is in hierdie sin onbelangrik nie. God is nie elders met groter dinge besig nie. Visie, soos hierbo verduidelik, beteken om hierdie groter prentjie te sien. Onderskeiding, soos hierbo verduidelik, beteken ook om die besondere belang van elke konteks te onderskei. Daar mag gemeentes wees wat, in die oë van ons hoogs materialistiese samelewing, meer strategies is in die koms van die Koninkryk. So mag gemeentes in middestede tans in Suid Afrika strategies vir die Koninkryk meer belangrik lyk en waarskynlik wel baie belangrik wees. Die interessante is dat 'meer strategies belangrik' in hierdie verband direk met groter nood en meer geleentheid tot diens verband hou. Hier is inderdaad dikwels sprake van 'downward mobility' in terme van strategie en loopbaan ontwikkeling ${ }^{106}$. In die gewone sin van die konsep 'loopbaanontwikkeling' lê die klem anders. Die vraag is dan meermale 'waar is dit beter, makliker, meer betalend'.

Kew \& White argumenteer vir 'n nuwe manier van 'calling a new breed of leaders'. Hulle wys daarop dat baie opleidingsinrigtings volhou met hulle fokus op die verlede, volhou met ' $\mathrm{n}$ sisteem wat deur modernisme gevorm is: "This is no way to train a generation in the vanguard of those grappling with the challenges of a confused and spiritually hungry Information Age...Tinkering in these times is insufficient. In considering the ways we should think about reordering theological education, we might do well to remember a line written by Lord Tennyson, Queen Victoria's poet laureate: "The shell must break before the bird can fly". Hulle verwys vervolgens daarna dat die meeste kritiek lê op die vlak dat die opleidingsinrigtings uit voeling is met die gemeentes. 'This being the case, it is inevitable that congregations will ask probing questions about the sort of job seminaries are doing, as they try dealing with the stresses being placed upon their often ill-equipped clergy. Liturgical correctness is a weak substitute for deep spirituality or evangelistic preaching, pastoral skills or biblical literacy, ${ }^{107}$. Van hierdie nuwe vrae wat gevra moet word, is indringend. Kew en White verwys na ' $n$ vraag van Michael Green, vir ' $n$ lang tyd self ' $n$ dosent, " $n$ 'seminary dean' en begaafde Nuwe Testamentikus: whether our priority is to prepare a cadre of future leaders with theological

106 Vgl Kew \& White (1997:47).

107 Kew \& White (1997:49-50). 
specialities or to form them in Christ as pastors, equippers, and evangelists? ${ }^{108}$. Niemand wie se werk ek gelees het, ook nie Kew en White nie, vra vir een oomblik die vraag of publieke pastorale leiers in gemeentes teologies opgelei moet word nie. Die erns wat deurdring is dat indien hierdie inrigtings nie vir die gemeente en vir die eise van die tyd waarin die gemeente gemeente moet wees, oplei nie, het beide sodanige inrigtings en die kerk ernstige probleme. Schaller se opmerking mag dan nader aan die waarheid wees as wat baie kerke en teologiese inrigtings graag sou wou erken: 'Or will small churches be staffed by bivocational ministers, retirees, and bivocational teams while the seminaries provide the pastors for the middlesized and large churches and the teaching churches train the future pastors of the very large congregations?"109. Kew en White, in opvolging van die vraag van Green of ons 'pastors, equippers, and evangelists' wil oplei, skryf: 'They should be schooled in the scriptures and, using everything from the church fathers to modern apologetics, be able to think theologically about the pastoral and evangelistic challenges facing a church that is now a body of "resident aliens" on a secular landscape,"

Ek het hierdie en ander ervarings van gemeentes en kerke ook in my vorige artikel genoem: Die gemeente speel ' $n$ deurslaggewende rol. Die behoefte word gevoed deur die 'painful personal disappointments" ${ }^{111}$ en die 'frustration churches feel with seminaries that are more closely identified with the academic and scholarly pursuits than with the churches and their pressing needs ${ }^{\text {,12. Die }}$ 'isolasie' waarbinne opgelei word en die beskerming van wat ' $n$ eensydige klem op universitêre akademie is, maak opmerkings soos die volgende ernstig: 'despite protests to the contrary, learning is seen primarily as the acquisition of information rather than inculcating the ability to think theologically or be formed for the ministering life - which involves laying the foundations for life-long study and exploration of ministry's challenges'. In die verband moet ' $n$ ondersoek in die VSA ernstig geneem word: in navraag na wat

108 Green \& McGrath (1993:169).

109 Schaller (1995:125).

110 Kew \& White (1997:54).

111 Elliston (1995:8-10).

112 Gibbs (2000:99). 
lidmate as die eerste prioriteit stel in hulle pastors 'an overwhelming majority of laity responded that they valued a mature level of spirituality. The preponderance of seminary professors surveyed, however, considered theological knowledge most importance, while quality of spiritual life appeared nowhere on their list of priorities $^{113}$. My rede vir hierdie aanhalings is om die erns van die saak te beklemtoon. Daar is ' $n$ gaping aan die ontwikkel en dit is gevaarlik. Ek kan nie anders nie as om te stel dat dit op die lang termyn geen voordeel inhou vir teologiese opleiding en vir die kerk nie.

Die kerk vervul sy roeping in ' $n$ tyd wat baie dinge radikaal en waarskynlik vir altyd verander het. Die boeke van Gibbs en Callahan is baie goeie materiaal om hierdie fenomenale skuiwe te probeer verstaan $^{114}$. Die gemeente moet sy roeping in hierdie nuwe samelewing vervul en nuwe eise word aan die publieke pastorale leier gestel. $\mathrm{Na}$ ' $\mathrm{n}$ skerp aanhaling uit ' $\mathrm{n}$ boek van Mike Regele oor die gebrek aan leierskap in die hoofstroom kerke stel Gibbs tereg dat elke teologie student hom of haarself die vraag moet afvra: 'Do I regard my education as providing prestige and security in future? Or do I consider it as essential preparation for a high-risk mission? ${ }^{\prime 15}$.

In die geval van die publieke pastorale leier behoort die verstaan van roeping te verander van ' $n$ beroep binne ' $n$ relatief veilige geloofsgemeenskap tot die verstaan van ' $n$ beroep, ' $n$ missionêre roeping met hoë risiko's. Die verstaan van die missionêre identiteit van die kerk verplig die geroepene hiertoe. Die missionêre gemeente verstaan (staan midde in) die dinamiese verhouding tussen kerk, evangelie en die samelewing. Hier is daar geen gemaksone waar onbekostigbare luukshede in stand gehou word nie. Die gemeente wat homself so verstaan is inderdaad ' $n$ ' at risk community'. Die Bybel getuig hiervan. 'n Hele nuwe 'stel spelreëls' geld vir diegene wat die missionêre gemeente tot doelvervulling begelei en versorg ${ }^{116}$. Dit is waarskynlik een van die redes waarom opleiding in gemeentes so toeneem. Literatuur oor 'church-based training' gee toe dat hierdie opleiding onvoldoende is. Gibbs sê tereg: "they are in danger of being so competency-based that they

113 Kew \& White (1997:52).

114 Gibbs (2000); Callahan (2002).

115 Gibbs (2000:97); Regele \& Schulz (1995:96).

116 Vgl Callahan (2000:31). 
fail to provide theological and missiological foundations and critiques to ensure that the growth they seek to enhance is authentic and substantive in terms of kingdom values" ${ }^{\prime 17}$. Wat wel ernstig is en erken moet word is dit: die gemeente en die rol van die gemeente word in hierdie 'church-based' opleiding ernstig geneem.

"Die ideaal is samewerking tussen opleiding en gemeente. Die doel is om hier te beklemtoon dat die 'werkgewer', in hierdie geval die gemeente (en die kerkverband), die reg het om die beroep wat hier beoefen word te vul met inhoud. Wie hom/haar hiertoe geroepe weet, weet dan meteen ook wat haar/sy beroep inhou en wat die eise aan die beroep en die voortgesette beoefening daarvan inhou. So iemand weet wat opleiding tot en voortgesette opleiding binne die beroep beteken. Dít is die beroep, dít is die vereiste opleiding en dít is die voortgesette opleiding vir iemand wat in die beroep wil bly" ". Ek is saam met Gibbs oortuig dat "local churches need to play a far more active part in recruiting and mentoring individuals they deem suitable for receiving further training" $"$.

Kew en White verwys na die vereistes binne die Anglikaanse kerkwêreld waar dit tot die taak van die kerk behoort om huidige en toekomstige behoeftes vir die bediening in gemeentes te identifiseer en ook 'recruiting and selecting people for holy orders' ${ }^{120}$. Hierdie taak word na my waarneming en literatuur ondersoek oral verwaarloos. Kerke wag vir vrywilligers om aan te meld. Hiermee word die individuele 'sense of being called to Christian Leadership' verhef bo die behoeftes van gemeente en aktiewe werwing. Individuele ervaring van roeping word verhef bo korporatiewe ervaring van roeping. Die kreatiewe tussenspel tussen hierdie twee dimensies van die waarheid van roeping word verloor. Kew en White maak ' $\mathrm{n}$ opmerking oor persone wat die publieke bediening in ' $n$ gemeente as tweede loopbaankeuse oorweeg, wat krities is: as toegewyde en dikwels 'ervare Christene' 'they are seeking a change in their business or personal life....Many who are ordained (na baie opofferings in terme van finansies ens.) ...may make wonderful pastors in the old model, but we have ask, "are they the best people

117 Gibbs (2000:99); Elliston (1995).

118 Nel (2002:151-167)

119 Gibbs (2000:94).

120 Kew \& White (1997:50). 
to lead the church over this cusp of history ${ }^{121}$. Kew en White is myns insiens korrek: ons het die proses omgekeer. Ons laat dit aan individue oor en hulle moet die kommissies en die akademiese inrigtings oortuig en dan word hulle deur legitimering en/of ordinasie vir en ook in/op die kerk 'losgelaat'. 'However, if we are to attempt to develop a more biblically-based approach to selection of leadership (see Acts 6:1ff.), is it not far more appropriate for the Christian community to seek out and identify those who have gifts for leadership, call them to the job, and set them apart for the task? Leadership abilities cannot be implanted during three years in a seminary, but they can be recognized, some possibly at an early age, by the believing community - then honed and further developed, ${ }^{122}$. Ten opsigte van die gevestigde patroon skryf Mulholland reeds in 1976: 'generally speaking, that pattern consisted of extracting young unproven, single, usually male volunteers from their home environment to train tehm in a centrally located institution...After three years these young people were declared pastoral material if they had successfully passed...., 123 .

Gibbs, wat self ook dikwels na Kew en White verwys, skryf in dieselfde verband: wanneer hierdie individualisering van roeping en bediening ook deur opleidingsinrigtings geduld en selfs bevorder word (omdat die drang en versoeking altyd daar is om soveel as moontlik 'preservice' studente toe te laat om in te skryf); wanneer daar in hierdie proses ' $n$ minimum mate van betrokkenheid, keuring en goedkeuring deur die plaaslike gemeente is, is dit onvermydelik dat standaarde verlaag. Volgens Gibbs is daar juis in hierdie opsig ' $n$ groeiende kommer oor die vermoë van opleidingsinrigtings om die mees belowende studente te trek. "Local churches need to play a far more active part in recruiting and mentoring individuals they deem suitable for receiving further training, ${ }^{124}$. Die uitdagings wat die gemeenskap aan die kerke en bediening van die pastorale leier stel, vereis meer en beter teologies geïnformeerde onderskeiding, nie minder nie. Hierdie onderskeiding sluit myns insiens nie net goeie

121 Kew \& White (1997:50).

122 Kew \& White (1997:50-51).

123 Mulholland (1976:5).

124 Gibbs (2000:93-94). Vgl ook sy verwysing na Schaller (1994:21) en Miller (1997:188) wat soortgelyke standpunte inneem. 
teologie as sodanig in nie, soos wat Gibbs ook bepleit ${ }^{125}$, maar ook die verruiming van die goed geïnformeerde onderskeidings basis van individu tot geloofsgemeenskap. Hierdie basis en ruimte van onderskeiding is belangrik, om teologiese redes per se, maar ook om wat genoem kan word teologies strategiese redes: 'Leadership emerges through demonstrated competence in specific areas, ${ }^{126}$. Hiervoor is die geloofsgemeenskap belangrik en nodig. Hier word karakter, charisma en kompetensie opgemerk, onderskei, ondersteun en ontwikkel. Voordat pastorale leierskap deur die denominasie 'publiek' verklaar word en namens die kerk in sy verband uitgeoefen word, is minstens een gemeente se kontrole nodig: mense, ook gelowige mense, wil eers vertrou en dan volg ${ }^{127}$. Om dit op hierdie punt saam met Barna te sê: 'A leader is someone who is called by God to lead and possess virtuous character and effectively motivates, mobilizes resources, and directs people toward the fulfillment of a jointly embraced vision from God" ${ }^{\text {"128 }}$.

Kew en White dink dat ' $\mathrm{n}$ nuwe benadering in die werwing deur middel van die gemeente sal lei tot groter diversiteit in die leierskap. En belangriker nog: jonger leiers wie se gawes reeds in gemeentes operasioneel is, word ingeskakel. Op die oomblik moet baie van hierdie Gen $X$ leiers in para-kerklike organisasies tereg kom. Hulle moet dikwels vanweë die onvermoë (of onwilligheid) van die kerk hulle gawes en bydrae elders ('buite die georganiseerde kerk') uitleef. En dit terwyl die nuwe soeke na spiritualiteit juis die meer gevestigde tradisies en liturgieë aantreklik maak. Ek dink dat hulle reg is wanneer hulle na Gen $X$ se ontnugteringe verwys en sê: "we will continue to do ourselves irreparable harm if we go on excluding Generation $\mathrm{X}$ from the ranks of the ordained while they are still relatively young, ${ }^{129}$.

Samevattend: die gemeente is krities in die werwing en keuring van die toekomstige publieke pastorale leiers. Die gemeente keur in elke geval. Hulle weet wie 'maak' dit in die publieke bediening

125 Gibbs (2000:99).

126 Gibbs (2000:113).

127 Vgl Gibbs (2000:114).

128 Barna (1998:107).

129 Kew \& White (1997:51). Vgl ook Congar (1967:369). 
tussen, teenoor, vir en as een van hulle. Enige persoon is welkom om teologie te studeer. Die kerk kan nie meer bekostig om persone wie se gawes slegs maar nog potensiëel is, ongekeurd, op te lei en dan die 'keuring' byna eksperimenteel aan die gemeente (gewoonlik die eerste een na opleiding) oorlaat nie. Om te redeneer dat indien dit sou geld toe 'ek' opgelei is, 'was 'ek' miskien nie in die bediening nie', is nie ' $n$ geldige argument nie. En indien die argument gebruik word, is dit nog een meer bewys dat die individualisme dieper ingedring het in denke en praktyk as wat enige Christelike kerk kan bekostig sonder om sy Christelike karakter in te boet (of sy identiteit te verloën en verloor).

Om dit net vir " $n$ oomblik weer van die ander kant saam te vat: Wanneer die gemeente by die werwing van pastorale leiers vir verdere teologiese opleiding ingeskakel word, is dit belangrik dat die kerk en persone duidelikheid het oor watter opleiding verlang en gegee word. Pobee is reg wanneer hy dit soos volg saam vat: Almal moet in gedagte hou watter gawe, spesifieke charisma in opleiding in belang van die opbou van die gemeente verfyn word. Alles is nie altyd van die begin af duidelik nie, maar dit is die verantwoordelikheid van die kerk, die opleidingsinrigting, die dosente en nog ander om individue te help om hulle spesifieke bediening te ontwikkel en uit te oefen. Dit mag nooit net maar aangeneem word dat wanneer jy aan alle opleidingsvereistes voldoen het, legitimering en/of ordinering ' $n$ voldonge feit is nie. Die gemeente moet ingeskakel word in die uiteindelike beslissing: 'The theologians, i.e. the articulate individuals in the womb of the church, should help the institutional church to draw up these priorities ${ }^{, 130}$. Publieke pastorale leiers se taak is onder andere om saam met en soms ook namens hierdie 'teoloë in die boesem van die kerk' 'to be God's mouthpiece or linguists in society and the world" ${ }^{131}$.

\subsubsection{Die Kerkverband: werwing, keuring en opleiding}

Ek aanvaar as gegewe dat kerkverband verstaan word as die verband van gemeentes wat deur hulle gemeenskaplike belydenis van God Drie-enig met mekaar in verband tree en in belang van hulle verstaan van bediening in verband met mekaar besluit en optree. Wie binne die kerkverband tot die publieke pastorale leierskap toegelaat word,

130 Pobee (1993:5).

131 Pobee (1993:5). 
is krities vir die gemeentes binne verband en die verband as sodanig. Wat in baie reëlings binne kerke gebeur, is dat die verband die taak van werwing en keuring kry en oorneem. Die kerkverband het egter nie die vermoë om dit te doen nie. Die verband kan en moet wel ' $n$ belangrike rol in keuring speel, maar wanneer dit by werwing kom, staan die kerkverband redelik magteloos. Die gemeente is primêre werwer en keurder en moet deur die verband daarvoor gebruik en daartoe bemagtig word.

Die kerkverband (gemeentes in verband) kan dus wel die nodige beleid vir werwing, keuring, opleiding, ordening en voortgesette opleiding bepaal. Wanneer dit in plek is, is werwing primêr die taak van gemeentes. Binne die plaaslike gemeente is die bediening op grondvlak en aantreklik naby aan hulle wat geroep word en daartoe begenadig (begaafd) is. Self die eerste vlak van keuring sowel as die uiteindelike aanvaarding van die gekeurde opgeleide (in terme van ' $n$ beroep) berus by die gemeente. Die verband kan homself en die gemeentes in verband baie pyn spaar indien hierdie ritme herstel word. ' $n$ Eerste vraag aan elke nuwe kandidaat behoort te wees: "wat sê die gemeente waar jy jou doop uitleef van hierdie roeping en beplande opleiding tot publieke pastorale leierskap'. Binne talle denominasies mag dit beteken dat die verband allereers sal moet meewerk aan die vestiging van ' $n$ nuwe kultuur by gemeentes vir die hele saak waarom dit in hierdie navorsing gaan. Dit is ongelukkig waar dat baie gemeentes en self kerkverbande geen opvallende passie en visie vir teologiese opleiding het nie.

Wat sou tot so ' $n$ beleid waarvolgens (in die plaaslike gemeente) gewerf en gekeur word, behoort? Minstens die volgende:

* Deelname van gemeentes aan die opstel van kriteria vir publieke pastorale leierskap in die spesifieke omgewing waar die gemeente is. Hierdie lys moet eerlik oop wees. Natuurlik behoort daar konsultasie te wees. Van die kriteria ten opsigte waarvan die verband 'prinsipieel' sterk mag voel, is:

$+\quad$ Gebalanseerde geloofslewe as dissipel van Christus;

$+\quad$ Aanvaarbaar in terme van menseverhoudings;

$+\quad$ Vermoë om te kommunikeer;

$+\quad$ In staat en bekend vir geloof-deling in ' $n$ nie-konfronterende relasionele styl; 
+ Diensbaarheid in gemeente en samelewing wat pas by die ouderdom en geleenthede beskikbaar;

$+\quad$ Goeie skool rekord in terme van intellektuele vermoë;

$+\quad$ Onderrigbare gees, openheid en relevante kreatiwiteit;

$+\quad$ Nederigheid;

$+\quad$ Onderskeiding en bevestiging van roeping tot hierdie vorm van bediening ${ }^{132}$.

Ek dink dat Heitink dit goed opsom wanneer hy skryf dat in ' $n$ tyd van teruglopende belangstelling in georganiseerde godsdienstigheid 'sal dit in ' $n$ toenemende mate aankom op persoonlike beïnvloeding, besieling, entoesiasme, outentisiteit en kreatiwitiet. Dit beteken dat in die predikantskap die persoon meer sentraal te staan kom. Uitstraling, charisma is belangrik' (vry, maar direk vertaal MN) ${ }^{133}$.

* Die opleiding wat vir hierdie publieke pastorale leierskap vereis word. Gemeentes in verband kom ooreen oor wat tot die 'beroep' behoort en wat die vereistes vir die opleiding tot en behoud van die bevoegdheid behels. Op hierdie punt mag denominasies verskil. Sommige sal " $n$ graad in die teologie vereis, ander " $n$ denominasionele diploma. Waaroor daar hopelik groeiende konsensus, selfs tussen kerkverbande, ontwikkel, is die noodsaak van opleiding en die verpligting tot voortgesette opleiding vir die behoud van die voorreg van publieke pastorale leierskap binne die bepaalde kerkverband.

* Die verband voorsien duidelike riglyne, soos reeds in sommige kerkordes vervat, oor die toelating vir en behoud van bediening. Hier behoort die klem te verskuif vanaf hoe bevoegdheid verloor kan word tot hoe dit behou word. Dit beteken onder andere:

+ Deelname aan 'bediening onder begeleiding' gedurende die eerste 3-5 jaar in die bediening. Hierdie begeleiding kan in oorleg met ' $\mathrm{n}$ ander leraar in span- of in Ringsverband georganiseer word.

$+\quad$ Voortgesette Teologiese Opleiding gedurende die eerste 3-5 jaar wat minstens 08 Opleidings Eenhede (OE) ('Training Units' TU) per jaar insluit. Hierdie eenhede word tans bereken teen $1 \mathrm{OE}$ vir elke 10 evalueerbare kontakure met ' $n$ dosent en studiemateriaal

132 Vgl Dittes (1990:21-26).

133 Heitink (2001:227). 
in ' $n$ kursus en/of seminaar. Die gemeente en die kerkverband help met die begroting vir hierdie voortgesette opleiding.

$+\quad$ Voortgesette Teologiese opleiding vir ' $n$ verdere vyf jaar teen 5 Opleidings Eenhede per jaar. Plaaslike gemeentes word gevra om tot hierdie begroting by te dra.

$+\quad$ Voortgesette Teologiese opleiding vir die res van die bediening teen 3 Opleidings Eenhede per jaar. Plaaslike gemeentes word gevra om tot hierdie begroting by te dra.

$+\quad$ Gereelde deelname aan opnames oor behoeftes van publieke pastorale leiers en aan internasionaal gestandaardiseerde meting instrumente oor wat genoem word 'profiles of ministry'. Hierdie 'meting' sluit in sake soos: 'responsible and caring; family perspective; personal faith; potential negative; ecclesial ministry; conversionist ministry; social justice ministry; community and congregational ministry ${ }^{134}$.

* Die kerkverband, in oorleg met opleidingsinrigtings en in detail konsultasie met gemeentes, beplan die opleiding en voortgesette opleiding wat vir effektiewe roepingsvervulling sowel as vir die pastorale begeleiding van die publieke pastorale leier nodig is.

Bogenoemde is belangrike elemente van ' $n$ werwing en keuringsbeleid. Elkeen wat die gemeente met 'n roeping tot publieke pastorale leierskap nader óf elkeen wat deur die gemeente as 'geroepene met operasionele gawes' geïdentifiseer word, moet so presies moontlik weet wat gemeentes binne hierdie verband (die kerkverband dus) van toekomstige publieke pastorale leiers verwagnie net om in te kom nie, maar om binne hierdie bediening te bly. Dit is my oortuiging dat die kerk geen keuse het as om op hierdie punt meer professioneel op te tree nie ${ }^{135}$.

\subsubsection{Die Kerkverband: keuring, opleiding en toelating}

Ek gaan nie probeer om die prosedure tot toelating in detail te beskryf nie. In baie denominasies is dit 'ou' gevestigde tradisies. Ek

\section{Aleshire (1990:97-103).}

135 Ek herhaal weer dat dit nie hier my bedoeling is, om die inhoud van teologiese opleiding te beskryf nie. Dit is egter logies dat dit deel is van die taak van die kerkverband om voortdurend en ernstig oorleg te pleeg met die instansies wat die moontlike toekomstige publieke pastorale leiers oplei. 
wil graag die klem laat val op wat die kerkverband in oorleg met die gemeente kan doen om te keur. In die proses gaan ek drie kerke se manier van doen kortliks beskryf.

\subsubsection{Presbyterian Church (U.S.A.)}

Binne die Presbyterian Church (U.S.A.) is die prosedure in detail uitgespel. Die Kerkorde reflekteer die erns van die saak. Die Handleiding vir die "Preparation for Ministry in the Presbyterian Church (U.S.A.) beskryf die proses in 49 bladsye. Die rol van die persoon wat navraag doen ('inquirer') en later kandidaat word, die rol van die plaaslike gemeente, die ring, die sinode, die opleidingsinrigting, die 'General Assembly' word hierin beskryf. Die teologiese uitgangspunte is in bree trekke in lyn met wat in hierdie navorsing oor roeping en die eise ten opsigte van opleiding vir 'ministers of Word and Sacrament' (hulle term) beskryf is ${ }^{136}$. In aansluiting by die amptelike dokument van die denominasie is daar verskeie ander inligting wat byvoorbeeld vir gemeentes en vir ringe ontwikkel is. So byvoorbeeld verskyn 'n dokument in Junie 2003 vir die 'Presbytery of Monmouth, NJ' onder die opskrif: 'Committee of Preparation Policy Manual'. Die amptelike hersiene dokument van die denominasie is pas weer in 2004 nuut gepubliseer: 'Manual: Preparation for Ministry in the Presbyterina Church (U.S.A.) ${ }^{137}$. Ek beskryf hierdie proses in meer detail omdat die proses beter gedokumenteer is. My aanhalings kom (behalwe waar anders aangedui) uit die amptelike dokument en ek plaas telkens die bladsy nommer in hakies na die aanhaling.

As een van die uitgangspunte tot die proses geld dat alle gelowiges in die bediening is en deur 'geordendes' (hulle begrip) opgelei word vir hulle bediening. Vir hierdie doel 'the church seeks and ordains persons whose gifts and abilities equip them for the ministry of Word and Sacrament'(3).Wat is die konsekwensies hiervan?

* Vir die gemeentes beteken dit dat alle lidmate moet verstaan dat hulle roeping tot dissipelskap verantwoordelike beroepskeuses insluit. Dit beteken ook 'nurturing and encouraging persons seeking to discern their call to the ministry of the Word and Sacrament'(4).

136 Vgl Heitink (2001:229); Schner (1993:41).

137 Office of Resourcing Committees on Preparation for Ministry (2004). 
* Vir voornemenende kandidate ('inquirers and candidates') wat in die proses inkom beteken dit 'a sense of solemn obligation to God and to the church. In some cases this means that it is the individual's responsibility to recognize and accept the fact that she or he is called to a ministry other than the ministry of the Word and Sacrament' (4).

* Vir ringe beteken dit die ontwikkeling van effektiewe maniere van toetsing en onderskeiding van die egtheid van die roeping, die voorsiening van begeleiding en toesig, die toesien dat diegene met die toepaslike vermoëns en motivering toelating tot 'candidacy' verkry. Om te verseker dat hierdie werk effektief gedoen word, moet diegene wat in die 'Committee on Preparation for Ministry' dien besondere gawes, vaardighede en toewyding hê (4).

Die proses self het twee fases: 'Inquiry phase and candidacy phase'. Die doel is 'to explore the call, evaluate the gifts, and support the preparation'(4). In die fase van 'navraag' word aan die gemeente en aan die individu die geleentheid gegee om saam met mekaar die roeping te ondersoek en toets (5). 'To make this exploration as effective as possible, a network of caring, supportive relationships is initiated - first, between the Inquirer and the church session, then with the presbytery through its Committee on Preparation for Ministry, and with the theological institution' (5).

'n Lidmaat word vir aanmelding ('enrollment') as ' $\mathrm{n}$ 'Inquirer' oorweeg wanneer sy of hy die kerkraad nader in verband met die moontlikheid om ' $n$ publieke pastorale leier te word. Van so iemand word verwag 'to formally agrees with the session and with the presbytery's Committee on Preparation for Ministry to explore the implications of this quest. Enrollment is intended to be a thoughtful and deliberate step; people are encouraged to take this formal action soon after they have made their personal decision to explore this ministry so that the presbytery's Committee can provide them support and counsel as early as possible'(6). Voordat so 'n 'Inquirer' aansoek om kandidaatskap (toelating tot teologiese opleiding met die oog op 'the ministry of Word and Sacrament') kan doen, moet die voornemende student minstens een keer per jaar met die ring se 'Committee on Preparation for Ministry' samespreking voer. Hier word spesifieke areas van groei beoordeel en nuwe doelwitte gestel. Wanneer so ' $\mathrm{n}$ persoon wel om toelating aansoek doen is dit die kerkraad van die gemeente waar die kandidaat aktief is wat kandidatuur by die ring aanbeveel. Hierdie aansoek prosedure is duidelik uitgespel. Die proses vereis wel dat die kerkraad minstens 
eenkeer met die voornemende kandidaat in oorleg met die 'Committee on Preparation for Ministry' gesprek voer. Verder vind minstens een verdere gesprek met die 'Committee on Preparation for Ministry' plaas. Die ring self keur uiteindelik die aanbevelings goed (6).

Tot die kandidaat fase behoort die ondersteuning van diegene wat tot kandidaatskap toegelaat is in hulle voorbereiding vir die publieke bediening as pastorale leier (7). Dit is die verantwoordelikheid van die ring se 'Committee on Preparation for Ministry' om ' $n$ omgewing te skep waar die uniekheid van elke kandidaat ernstig geneem word. 'As partners in a covenant relationship ${ }^{138}$, both the Committee and the Candidate are encouraged to work together as they plan for and evaluate the Candidate's growth and development...An Inquirer becomes a Candidate by action of presbytery. At that time the Candidate formally agrees to accept the presbytery's supervision in her or his preparation for the ministry of the Word and Sacrament...The covenant relationship between the Candidate and the presbytery is expressed through the negotiation and review of a series of learning contacts based on the expected outcomes for this phase. In consultations that occur at least once a year, both the Committee and the Candidate assess her or his progress toward completion of previously established goals and negotiate appropriate new goals. It is essential that during each consultation the decision be made as to whether the Candidacy should be continued, especially if it becomes clear that adequate growth is not taking place' (7).

Van die uiterste belang in hierdie beleidsdokument is die detail waarin die doel en verwagtings verbonde aan elke fase beskryf word (16-35). Die pastorale gees waarin die dokumentasie geskryf is, is eweneens opvallend. Die 'kontrak' tussen gemeente, kerkverband, kandidaat sluit ook 'continuing development' in (10) ${ }^{139}$. Aktiewe inskakeling as lidmaat in die gemeente is voortdurend deel van die evaluerende gesprekke (vgl 19). So ook is die skryf van jou 'storie' (soms deur middel van die invul van standaard vorms) deel van die proses. Vir die plaaslike gemeente wat die aanvaarding van die

138 Kandidate onderteken formeel ' $\mathrm{n}$ 'Covenant Agreement between Inquirer, Session and the Committee on Preparation for Ministry’ Form 2B, 47.

139 Vgl Presbyterian Church (U.S.A.) (2003/2004:Part II, G-14.0305). 
'Inquirer' moet ondersteun en goedkeur word byvoorbeeld duidelike riglyne verskaf:

* $\quad$ watter persoonlike kwaliteite ten opsigte van ' $n$ persoonlike en lewende geloofslewe is opvallend;

* Hoe kom die geloof tans tot uitdrukking deur die individu se deelname aan die erediens, lewe en missie van die gemeente;

* Watter is die motivering vir die roeping (bv diens aan God en wêreld, passie vir God se kinders, skuldgevoelens, die behoefte aan mag en posisie?);

* Watter werklike talente vir die bediening is opvallend in die lewe en betrokkenheid van die individu" (bv die vermoë om te kommunikeer, interpersoonlike vermoëns, leierskap, administratiewe vermoëns);

* Wat is die vlak van bekwaamheid rakende akademiese vermoë, vaardighede en motivering;

* Wat is die getuienis oor fisiese gesondheid en uithouvermoë;

* Watter getuienis is daar oor emosionele gesondheid;

* Watter getuienis bestaan oor self-dissipline;

* Hoe beplan die individu om vir die opleiding te betaal (24).

Vir die ring word ' $\mathrm{n}$ soortgelyke raamwerk van vrae verskaf om voortdurend in gesprek met die Kandidaat te beoordeel. Dit raak 'personal issues, educational issues, situational issues, and occupational issues' (29-30). As hulpbronne in die evaluering gedurende die 'Inquirer's' fase word 6 bronne genoem: 'career counseling, psychological evaluation, reports from the educational institution, reports and reflections on the Inquirer's participation in a Presbyterian congregation, letters of reference, persons experienced in interviewing techniques' (30-31).

In die Presbyterian Church (U.S.A.) 'ordination for the office of minister of the Word and Sacrament is an act of the whole church carried out by the presbytery' $(13)^{140}$. Die waarde van hierdie direkte kontak met die tuis gemeente en die 'ring' wat toelating tot 'kandidaatskap' gegee het, word so erken en behou. Hiervoor is

140 Presbyterian Church (U.S.A.) (2003/2004:Part II G-14.0401, 0402a,b). 
inderdaad ' $\mathrm{n}$ goeie saak uit te maak en kerke wat dit nie doen nie, moet ernstig nadink oor die vraag: waarom nie?

\subsubsection{Reformed Church in America en Christian Reformed Church in North America}

Binne die Reformed Church in America en die Christian Reformed Church in North America bestaan goed ontwikkelde sisteme van toetsing en 'evaluering' van uitslae. Die proses is min of meer dieselfde as wat hierbo beskryf is. Die rol van veral die 'classis' is belangrik. Beide kerke maak ruim en ook in oorleg met mekaar (veral in Michigan waar elkeen binne ' $n$ uur vanaf mekaar teologiese opleidingsinrigtings het) gebruik van psigologiese toetsing. ' $n$ Praktiserende psigoloog, Dr. Don Topp (ook ' $n$ opgeleide teoloog) is amptelik ingeskakel by die toetsing van teologiese studente by die seminarium van die RCA in Holland MI. In ' $n$ ongepubliseerde artikel skryf hy oor die belangrikheid van toetsing as sodanig, maar veral oor die belangrikheid van 'n multidissiplinêre benadering: 'the core team is comprised of persons who are well trained in psychology and clinical social work, as well as having theological training and ministry experience in parishes, specialized ministries, and community organizations ${ }^{141}$. Beide by Western Seminary en by Calvin Seminary word ' $\mathrm{n}$ battery van toetse gebruik. Van die bekendste is:

* "Clinical Interview: A personal interaction to gather history and expressions of personality characteristics, emotional health and interpersonal functioning.

* Feedback Interview: A second meeting to share feedback regarding the assessment results.

* 16 PF: A questionnaire that assesses characteristic interpersonal and situational coping styles.

* Minnesota Multiphase Personality Inventory-2: A test designed to measure personality traits that may foster or hinder effective functioning.

* $\quad$ Rotter Incomplete Sentences Blank: A test which assesses a person's perception of the world and seeks to identify positive and negative life adjustment patterns.

141 Topp (2003:3). 
* FIRO-B: A questionnaire designed to measure fundamental interpersonal relationship ability and orientation.

* Myers-Briggs Type Indicator: A questionnaire designed to survey preferred styles of perception, cognition and behavioral organization.

* Personal History Form: A questionnaire used to gather information about family, education, work and health" ${ }^{\text {"142 }}$.

Op grond van hierdie toetse en onderhoude word " $n$ individuele verslag van ongeveer 6-9 bladsye oor elke kandidaat voorberei. Langs die weg van groep-gesprekke en persoonlike onderhoude word terugvoer gegee. Uiteindelik is daar 'debriefing with core seminary faculty - academic dean, director of counseling, and director of formation for ministry'. Die integriteit van die proses word verseker deur die kwaliteit van opleiding van die lede van die span, maar ook deur die doel naamlik dat dit tot voordeel van die student, die kerk, die opleidingsinrigting en die koms van die Koninkryk is ${ }^{143}$.

\subsubsection{Willow Creek Community Church}

Die bekende Willow Creek Community Church het vir ongeveer vier jaar reeds ' $\mathrm{n}$ program vir die opleiding van persone wat hulle tot bediening en ook tot 'voltydse' bediening geroepe voel. In die bekendstellingsbrosjure word dit so gestel:

'Willow Creek community Church has joined Bethel Seminary in Minnesota to offer a comprehensive three-year internship program at the Willow Creek Campus in South Barrington, ILL. This experience is designed to provide you with the practical hands-on training and seminary education that will prepare you for a lifetime of fruitful service. You will receive practical training in ministry through the local church as you labor sideby-side with others who have dedicated their lives to full-time service in God's Kingdom. During your three years of study, you will receive direct experience with and supervision by the staff of Willow Creek Community Church. You will also earn a fully accredited seminary education: three years of theological study

142 Lys voorsien deur Prof Ron Nydam, Calvin Seminary, Grand Rapids, MI: Psychology Associates of Grand Rapids, PC.

143 Topp (2003:3). 
through Bethel Seminary, culminating in a master's degree in Church Leadership ${ }^{144}$.

Die doel van die opleiding is: 'to develop pastors who are biblically educated, trained in ministry and leadership skills, and internally transformed by Christ'. In antwoord op ' $n$ vraag waarom Bethel Seminary is die antwoord in die bekendstellings brosjure: 'First, we share the vision to train the next generation of church leaders. Second, Bethel is at the cutting edge of seminary education and is very interested in working with us. We are also open to partnering with other seminaries in the future ${ }^{145}$.

In 'n 50 uur per week program word die tyd soos volg verdeel:

* 9 uur met die 'Willow Creek Internship Director' waar persoonlik en in klein groepe aandag gegee word aan 'spiritual development and your transformational journey' Binne hierdie tyd word holisties na die 'mens' in opleiding gekyk: 'take the background of the person into consideration, go back to the basic beliefs of the individual and help in discerning the voice of God in the activities of the church'.

* 1 uur onder die supervisie van die senior personeel van Willow Creek oor bedienings-ontwikkeling en persoonlike groei.

* 15 uur van opleiding in ' $\mathrm{n}$ bediening van keuse (minstens 15 bedieningsterreine is deel van die keuse) en onderskeiding van gawes onder leiding van ' $\mathrm{n}$ 'ministry mentor'. Hierdie mentor word bepaal na onderhoude met sodanige bedieningsleiers. Die student kan van mentor verwissel en dit gebeur onder supervisie. Hierdie deel staan bekend as 'ministry training and experience'.

* 25 uur van bedieningservaring in die spesifieke terrein wat gekies of onderskei is en waarbinne die opleiding waarna in die vorige punt verwys is, plaasvind.

In direkte aansluiting by bogenoemde is die studies met Bethel Seminary. In ' $\mathrm{n}$ twee uur onderhoud met ' $\mathrm{n}$ senior 'intern' in die program, Deanna Fitzgerald 'n opgeleide apteker" ${ }^{146}$, vertel sy dat

144 Willow Creek Community Church (2).

145 Willow Creek Community Church (1).

146 Onderhoud Deanna Fitzgerald op die kampus van Willow Creek Community Church, Desember 15, 2003. 
hierdie opleiding vir ' $n$ 'masters in transformational leadership' (behalwe die opleiding in die gemeente, opleiding 'on line and live video') ook vereis dat hulle twee keer per jaar vir twee weke by Bethel Seminary klasloop met ongeveer 40 uur per week. Hierdie deel van die opleiding staan bekend as 'theological training'. Volgens Me Fitzgerald is die doel nie om vir Willow Creek Community Church op te lei nie. Die doel is om terug te gaan of om vir die voortsetting van bediening van Willow Creek Community Church weg te gaan.

Die proses om in die program in te kom is lank en deeglik. Die proses begin met ' $n$ twee uur telefoon onderhoud met voornemende kandidate. Indien iemand getroud is, word 'n onderhoud ook met die lewensmaat gevoer. Indien so ' $\mathrm{n}$ persoon hierdie rondte slaag, word hulle toegelaat om na Chicago te kom vir opleiding hoe om fondse te werf indien hulle nie selfonderhoudend is nie. Baie onderhoude met die 'ministry mentor', volg en selfs hier is daar nog ' $\mathrm{n}$ geleentheid om te besluit om nie met die program voort te gaan nie. Hierdie proses kan tot drie jaar voor jou werklike opleiding begin - afhangende van persoonlike omstandighede. Die ouderdom van die groep waarvan Me Fitzgerald deel is, is tussen 29 en 43. Slegs drie van die groep kom direk vanuit ' $n$ kollege waar hulle 'n eerste graad gedoen het. Drie referente, deur die voornemende student verskaf, word gevra om per voltooide vraelys inligting in te stuur. Daar is geen geskrewe aanduiding dat van hierdie referente uit ' $n$ 'tuisgemeente' moet wees nie. Studente moet wel by Willow Creek Community Church inskakel. Die aansoekvorm self handel, behalwe oor die gewone soos opleiding en kwalifikasies, oor ' $n$ persoonlik geskiedenis, bedieningservaring, geestelike gawes, leierskap invloed ('list two people (other than family) whom you have had the greatest influence or impact on:'..list two people you have discipled/ mentored' - what is your evangelism style'), roepingsgeskiedenis en wat jy glo rakende nege kritiese areas ${ }^{147}$. Sowel Willow Creek en Bethel vereis psigologiese toetsing en kan die student vir verdere toetsing en/of hulp verwys.

Vier verdere opmerkings is hier van belang. Van die studente word die volgende verwag en ten opsigte hiervan word hulle getoets:

147 Willow Creek Community Church (2003). 
* 'You should be convinced of a growing sense of God's leading into full-time ministry. Do you have mature believers who can support your sense of God's leading and who can point to 'spiritual fruit' that has been evident in your ministry life? Are you truly ready? Is this right for you?

* You must reflect a growing character and spiritual attitude that is in accordance with the fruit of the Spirit (Galatians 5:22-23). You must be a Christ follower for at least two years. You must be faithful, available, and teachable.

* You must be supportive of the ministry, values, and philosophy of Willow Creek Community Church. You should be willing to complete the participating membership course and become a member of Willow Creek Community Church or an affiliated Willow Creek Association church. You should maintain a positive attitude towards the staff, the church family, and other interns by modeling biblical unity and healthy conflict-resolution practices (Mt 18).

* You must consistently attend both weekend and New Community services. You ought to intentionally and regularly spend time with seekers, ${ }^{148}$.

\subsection{Samevattend}

2.3.1 Ten opsigte van hierdie afdeling is dit duidelik dat kerke poog om groter erns te maak met:

* Hulp aan voornemende studente om as deel van die liggaam van Christus hulle roeping te onderskei. Watter gemeente sou wou probeer om die roeping te ontmoedig. Watter gemeente en kerkverband kan egter bekostig om dit nie te help onderskei nie?

* Die plaaslike gemeente word binne die kerkvervand in hierdie geval die ring) ondersteun in die toelating tot die bedieningsopleiding. Dit is my oortuiging dat hierdie toelating eers behoort te geskied nadat ' $n$ student ' $n$ basiese graad in die geesteswetenskappe voltooi het. Binne die kerkverband waarvan ek deel is, betaal ons reeds die prys met die toelating van studente wat te jonk is (oor die algemeen gesproke) om selfs geïnteresseerd te wees in die basiese vrae wat die bediening raak en waarvoor toetsing nodig is.

148 Willow Creek Community Church (2003:7). 
* Die ring word die basiese kerklike liggaam wat in oorleg met en met die toestemming van die plaaslike gemeente toelating tot 'kandidaatskap' en opleiding vir die bediening verleen.

* Die gemeentes, die ring, die sinodes en die algemene sinodes (of wat sodanige vergaderings ook al in denominasies genoem word) besluit saam op die kwalifikasies vir, die vereiste opleiding vir en die vereiste voortgesette opleiding vir die publieke pastorale leiers binne die gemeentes van daardie denominasie.

* Opleiding vir die voltydse publieke pastorale leierskap in plaaslike gemeentes behoort baie nader aan en in oorleg met plaaslike gemeentes te gebeur. Wie hierdie uitdaging nie aanvaar nie, sal baie meer gemeentelike seminariums, soos díe in Willow Creek Community Church sien opskiet ${ }^{149}$.

2.3.2 In die eerste deel van hierdie navorsing is gestel dat, 'met inagneming van die sensitiewe en komplekse aard van die saak onder bespreking, dit my oortuiging is dat daar ' $n$ beter weg moet wees om gemeente en predikant te help. Die saak waarom dit gaan raak die eer van God en die koms van die Koninkryk. Dit raak God se wil. Die doel van die navorsing is onomwonde:

Om ' $\mathrm{n}$ weg te vind vir gemeentes en die kerk in verband ( en inrigtings waar predikante vir ' $n$ bepaalde kerk opgelei word) om op ' $n$ verantwoordelike wyse en met die nodige sensitiwiteit

1 geskikte kandidate vir die bediening te werf;

2 kandidate wat die roeping tot die bediening ervaar, te help om hierdie roeping voor en tydens opleiding te onderskei (keuring);

3 hierdie kandidate te begelei en op te lei;

4 kandidate wat kwalifiseer te legitimeer en orden tot algemene en besondere bedieninge;

5 geordende predikante gestruktureerd in te skakel by voortgesette teologiese opleiding (lewenslange leer) en beroeptoetsing ten einde ordening te behou en in die bediening goed toegerus, kompetent en vaardig te bly.

2.3.3 Die laaste woord is nie gespreek nie, maar dit is my oortuiging dat daar ' $n$ meer uitnemende weg is. Dat dit ' $n$ weg van die liefde is,

149 Vgl ook die bydrae oor 'Assessment in the future' in Hunt, Hinkle \& Malony (1990:198-205). 
is my oortuiging: liefde vir mense wat hierdie roeping ervaar, liefde vir die gemeente waar hierdie roeping onderskei en vervul word, liefde vir die kerk in verband waarbinne die gemeente(s) hulle per belydenis tuis vind, liefde vir die koms van die Koninkryk van God en liefde vir Hom wat roep en uit, deur en tot Wie alle dinge is (vgl. 1 Kor 12-14 en Rom 9-11).

2.3.4 Watter kerk gaan die moed hê om nie langer die sukses van voornemende publieke pastorale leiers aan 'trial and error' oor te laat nie? Watter denominasie het die moed om reformasie hier by een van sy wortels aan te pak? Watter opleidingsinrigtings het die moed om te reformeer, herstruktureer en herkurrikuleer om die ontstaan van teologiese opleiding binne gemeentes te voorkom, te beperk of te bestuur?

\section{Literatuurverwysings}

Aleshire, D O 1990. ATS Profiles of Ministry Project, in Hunt, R A, Hinkle, J E (Jr.), Malony, H N (Eds.) 1990. Clergy Assessment and Career Development. Nashville: Abingdon, 97-103.

Anderson, H. 2003. Introductory remarks on the Practices of Ministry. Ongepubliseerde lesing by die "First Call Theological Education, Summit", Daytona Beach, Florida.

Associated Mennonite Biblical Seminary (1994:6). Ministerial Formation and Theological Education in Mennonite perspective. Elkhart, Ind.: Associated Mennonite Biblical Seminary.

Banks, R 1999. Reenvisioning Theological Education. Exploring a Missional Alternative to Current Models. Grand Rapids: Eerdmans.

Barna, G 1998. The Second Coming of the Church. Waco, TX: Word.

Brouwer, R. 1005. Pastor tussen macht en onmacht. Zoetermeer: Boekencentrum.

Browning, D S, Polk, D \& Evison, I S (eds.) 1989. The education of the Practical Theologian. (Responses to Joseph Hough and John Cobb's Christian Identity and Theological Education. Atlanta: Scholars Press.

Callahan, K L 2000. Small, strong congregations. San Francisco: Jossey-Bass.

-, 2002. The Future has Come. San Francisco: Jossey-Bass.

Carroll, J W 1986. Ministry as Reflective Practice: a new look at the professional model. Washington, DC: Alban Institute.

Congar, Y 1967. Tradition and Traditions. New York: Macmillan. (Vertaal deur M. Naseby \& T. Rainsborough.)

Costas, O E 1979. The Integrity of Mission. The Inner Life and Outreach of the Church. San Francisco: Harper \& Row.

Dawn, M J \& Peterson, E H (ed. by Santucci, P) 2000. The unnecessary Pastor. 
Rediscovering the Call. Vancouver:Regent College.

Dittes, J E 1990. 'Tracking God's Call: Basic Theoratical Issues in Clergy Assessment', in Hunt, R A, Hinkle, J E (Jr.), Malony, H N (Eds.) 1990. Clergy Assessment and Career Development. Nashville: Abingdon, 21-26.

Elliston, E 1995. Church Based Training. Global Church Growth XXXII (1), 810.

Evangelical Lutheran Church in America Study of Theological Education. 1995. Faithful Leaders for a Changing World: Theological Education for Mission in the ELCA. ELCA: Report to the 1995 Churchwide Assembly.

Farley, E 1983. Theologia. Philadelphia: Fortress.

Firet, J 1977. Het agogisch moment in het pastorale optreden. Kampen: Kok.

-, 1988. The Fragility of Knowledge. Philadelphia: Fortress.

Freeman, F 1986. Readiness for Ministry through spiritual direction. Washington, DC: Alban Institute.

Friedrich, C J (ed. and translated) 1949. The Philosophy of Kant. New York: Modern Library.

Gibbs, E 2000. ChurchNext. Quantum changes in how we do ministry. Downers Grove: InterVarsity.

Green, M \& McGrath, A 1993. Springboard for Faith. London: Hodder and Stoughton.

Hall, J D 1988. "Theological Education as Character Formation". Theological Education, Vol. 24, Supplement 1, 53-79.

Hendriks, J \& Jonker, E 2000. 'Laat u geen meester noemen': Een praktischtheologische benadering van het leren als enkeling en het leren als gemeente. Praktische Theologie 27(2), 135-156.

Heitink, G 1993. Praktische Theologie. Kampen: Kok.

-, 1999. Practical Theology. Grand Rapids: Eerdmans.

-, 2000. Pastor in en lerende gemeente. Praktische Theologie 27(2), 223-230.

-, 2001. Biografie van de Dominee. Baarn: Ten Have.

Hess, E P 1991. Christian Identity and Openness: a Theologically informed Hermeneutical approach to Christian Education. Ann Arbor: U.M.I. (Phd. Princeton Theological Seminary).

Hough, J C \& Cobb, J B 1985. Christian Identity and Theological Education. Chicago,CA.:Scholar Press.

Hunt, R A, Hinkle, J E (Jr), Malony, H N (eds) 1990. Clergy Assessment and Career Development. Nashville: Abingdon.

Joerz, J C \& McCain, P T (eds) 1998. Church and Ministry. The Collected Papers of the 150th Anniversary Theological Convocation of the Lutheran Church - Missouri Synod. St. Louis: The Lutheran Church-Missouri Synod. 
Kant, Immanuel. "What is Enlightenment", in Friedrich, C. J. (ed. and translated) 1949. The Philosophy of Kant. New York: Modern Library.

Kew, R \& White, R 1997. Toward 2015: A church Odyssey. Cambridge, Mass: Cowley.

Klimoski, V J, 2003. Getting to the question: Assessment and the Professional Character of Ministry. Theological Education 39(1), 35-52.

Lieske, R.P. 1984. The Making of a Theologian. Selected Works of MH Scharlemann. St.Louis, MO: Concordia Seminary.

Lindbeck, G A 1988. "Spiritual Formation and Theological Education". Theological Education 24, Supplement 1, 10-32.

Luck, D G 1999. Why study Theology? St. Louis, MO.: Chalice Press.

MacInnis, John E. 2002. "Theological Education for Ministry", in Petersen, R L 2002. "Theology: What is the real thing?", in Petersen, R L \& Rourke, N M (eds) 2002. Theological Literacy for the Twenty-First Century. Grand Rapids: Eerdmans, 382-391.

McIntyre, A 1981. After Virtue. Nortre Dame, IN: University of Nortre Dame Press,

Miller, D 1997. Reinventing American Protestantism: Christianity in the new Millennium. Berkeley: University of California Press.

Mulholland, K B 1976. Adventures in Training for the Ministry. A Honduran case study in TEE. Philadelphia: Presbyterian and Reformed Presbyterian Church.

Nel, M 2001. Ek is die verskil. Bloemfontein: CLF.

-, 1994. Gemeentebou. Halfway House: Orion.

-, 2002. Predikante Opleiding: Roeping, Keuring en Legitimering. Verbum et Ecclesia 23(1), 151-167.

-, 2004. Who are we? Understanding and Finding Identity in the local Church. Pretoria: Malan Nel (printed by CopyMaster).

Niebuhr, H R 1956. The purpose of the Church and its Ministry: Reflections on the Aims of Theological Education. New York: Harper \& Row

Niehaus, R (ed) 1999. Theological Education and Moral Formation. Grand Rapids: Eerdmans.

Office of Resourcing Committees on Preparation for Ministry, 2004. Manual: Preparation for Ministry in the Presbyterian Church (U.S.A.). Louisville, KY: PC (U.S.A.).

O’Meara, T 1990. "Doctoral Programs in Theology in U.S. Catholic Universities." America, February 3, 79-103.

Petersen, R L 2002. "Theology: What is the real thing?", in Petersen, R L \& Rourke, N M (eds) 2002. Theological Literacy for the Twenty-First Century. Grand Rapids: Eerdmans, 1-12.

Pieterse, H J C 1993. Praktiese Teologie as kommunikatiewe handelingsteorie. 
Pretoria: RGN.

Pobee, J S 1993. "Ministerial Formation for Mission Today: An Introductory Statement", in Pobee, J S (ed) 1993. Ministerial Formation for Mission Today. Accra: Published for the Ecumenical Theological Education, WCC by Asempla Publishers, 5.

Presbyterian Church (U.S.A.), 2003/2004. Book of Order: The Constitution of the Presbyterian Church (U.S.A.).

Regele, M \& Schulz, M 1995. Death of the Church. Grand Rapids: Zondervan.

Report of the Working Party on Assessment of the Committee for Theological Education. 1987. Education for the Church'c Ministry. London: Advisory Council for the Church's Ministry, 33-34.

Rouch, M A 1974. Competent Ministry: a guide to effective continuing education. Nashville: Abingdon.

Schaller, L E 1994. Innovations in ministry. Abingdon: Nashville.

-, 1995. The New Reformation: tomorrow arrived yesterday. Nashville: Abingdon.

Schner, G P 1985. 'Formation as a unifying concept of Theological Education'. Theological Education, Vol. XXI, 2, Spring, 94-113.

-, 1993. Education for Ministry. Reform and Renewal in Theological Education. Kansas City: Sheed \& Ward.

Schoen, D 1983. The Reflective Practitioner. New York: Basic Books.

Schuth, K 1999. Seminaries, Theologates, and the Future of Church Ministry. An Analysis of Trends and Transitions. Collegeville, MN: The Liturgical Press.

St Anselm: Proslogium; Monologium; An Appendix in Behalf of the Fool by Gaunilon; and Cur Deus Homo. Vertaal deur Deanne, S.N. 1958. La Salle, ILL: Open Court Publishing Company.

Strege, M D 1992. "Chasing Schleiermacher's Ghost: The Reform of theologocal Education in the 1980's", in: Niehaus, R (ed) 1999. Theological Education and Moral Formation. Grand Rapids: Eerdmans, 113.

Tracy, D 1988. "Can virtue be taught? Education, Character, and the Soul". Theological Education 24, Supplement 1, 33-52.

-, 2002. “On Theological Education: A Reflection”, in: Petersen, R L \& Rourke, N M (eds) 2002. Theological Literacy for the Twenty-First Century, 13-22.

Topp, Don 2003. Psychological Evaluations by Topp Psychological Services. Ongepubliseerde notas. Holland, Michigan.

Van der Ven, J A 1998. Education for Reflective Ministry. Leuven (Louvain), Belgium: Peeters Press.

-, 2000. Pastoraal perspectief. Vorming tot reflectief pastoraat. Kampen: 
Kok.

Van Nijen, J 1995. Voorganger van professie. Praktische Theologie 22(2), 229.

Willow Creek Community Church 2003. What does it take to do minsitry fulltime? WCCC: South Barrington,.

Willow Creek Community Church 2003. Church Leader Internship: Frequently asked Questions. WCCC: South Barrington.

Willow Creek Community Church, 2003. Church Leader Internship: Application. WCCC: South Barrington.

Wood, C M 1985. Vision and Discernment. An Orientation in Theological Study. Atlanta: Scholars Press.

-, 1994. An invitation to Theological Study. Valley Forge, PA: Trinity Press International.

Wright, T 1999. The Ministry Marathon: caring for yourself while caring for the people of God. Nashville: Abingdon. 